\title{
$40 \mathrm{~mm}$ 人胎児の耳管及鼓室の局所解剖学的研究
}

\author{
日本医科大学解剖学教室（主任 横尾安夫教授） \\ 高田宗次郎 \\ Sōjirō Takata
}

人胎児の耳管及鼓室の発生学的研究飞資するため $40 \mathrm{~mm}$ 第 3 ケ月始め乃至中ばの 1 例火ついて，乞の発 育が周囲の発育状態と如何なる関原の下進行してい るかを明らかとする目的をるって，その前頭断連続切 片について桧索し，次の如き所見を得た。

\section{研 究 材 料}

横尾教室の $40 \mathrm{~mm}$ 人胎胃のツエロジン $25 \mu$ の前頭 断連続切片標本，ヘマトキシリン，エオシン染色。

所見

\section{軟骨及び骨}

軟滑

基戍板 Planum basale（図 1, 図 2)

頭蓋底の下垂体窝と大後頭孔の髁間切痕 intercondyloid notch との間の軟骨板で，外㑡部は薄い三日月

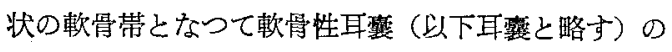

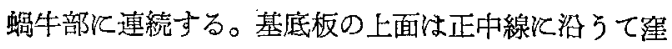
み，下面は凸状で，後僛部は最も低い位置に在る。蟜 牛部との連続部には上側に Sulcus basicochl. dors. 下側に Sulcus basicochl. ventr. がある。前部々蝶 形軟骨体部之蝠牛部之の間飞㹨くて深い sphenocochlear notch (図13), 後部は䫓静脈孔の下内側部, 後 頭部と蛤牛部との間に occipitocochlear notch 形 成する。基底板上面加ら上方へ鞍背が突出し, 斜台が その後につお゙く。

耳部 Regio otica（図1，図2)

的牛部と前庭部との 2 部分から成り, 両者はや小屚 平な手拳状で，前者は基底板外側に，後者は前者の外 後背側方に連続する。

蝸牛部の前端は翼突起 Proc. alaris の後方下よりに 在る。蛤牛部内側面後よりには顔面神経孔及内耳孔の 開口があり，その下面の後よりに Promunturium の 面があり, 蝸牛部下面後端部之後頭部との間飞頚静脈 孔が形成され，蝸牛部外面後上部にも顔面神経孔を認 める。

前庭部は螖牛部に連続してとの後や上外背方に位置 し, その後側部は頭頂板, 後頭鱗飞続く。内側面下部

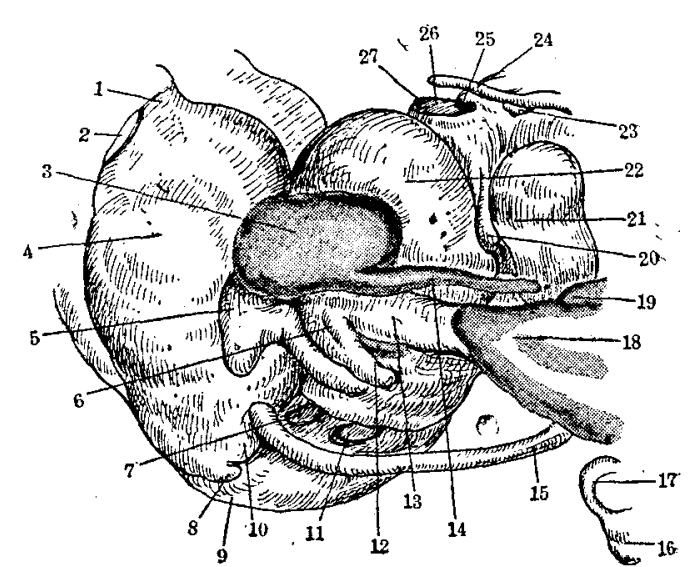

\begin{tabular}{|c|c|}
\hline 1 …側頭耳胞交連 & 15‥ラライヘト氏軟骨 \\
\hline $2 \cdots$ 側頭耳胞裂 & 16…甲状軟骨 \\
\hline $3 \cdots$ ‥側頭骨鳞 & 17…舌軟骨 \\
\hline $4 \cdots$ 前庭部 & 18…下䫟骨 \\
\hline 5 …呫軟罳 & $19 \cdots$ 煩骨側頭突起 \\
\hline 6 …檤軟，霄 & 20 …翼突起 \\
\hline 7 …頸静脈孔 & $21 \cdots$ 側頭翼 \\
\hline $8 \ldots$ 乳踭突起原基 & $22 \cdots$ 蝸牛部 \\
\hline 9 …骵旁突起 & $23 \ldots$ 視束交叉下翼 \\
\hline $10 \ldots$ Crista parotica & $24 \cdots$ 背側突起 \\
\hline 11…舌下神経管 & $25 \cdots$ 前鞍突起 \\
\hline $12 \cdots$ Tympanicum & $26 \cdots$ 下垂体窩 \\
\hline $13 \cdots \times ッ$ ル乾骨 & $27 \cdots$ 鞍背突起 \\
\hline
\end{tabular}

図 $140 \mathrm{~mm}$ 人胎玩の磌蓋軟骨及骨(右外側面)

に内リンパ孔開口し，その後方から下方へかけて横漕 を認める。外側面は螖牛部の外側面より治く隆起 乙, 上前側部に鼓室㦈 Tegmen tympani, 下前側部

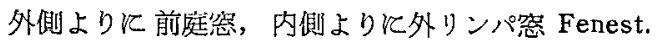
perilymphaticus を認め, 外下前側部に Crista parotica，その下後方に小さな乳嘴突起の原基が在る。

蝶形部 Regio sphenoidalis（図 1, 図 3)

蝶形体梳眼简間障 Septum interorbitale と基底板 との間の厚い敢骨で上部側化トルコ鞍があり, 鞍背は

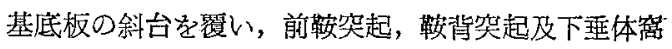

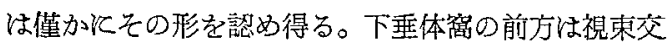




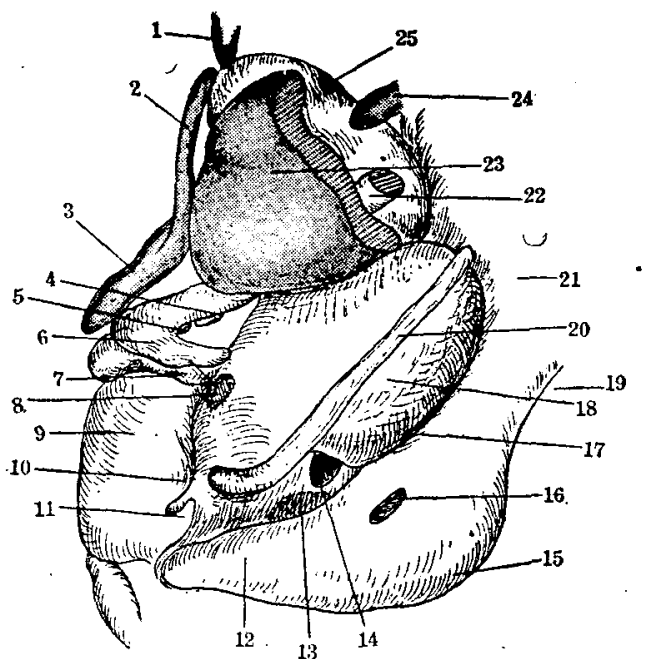

1 …煩骨例頭突起

$2 \cdots$ 側頭骨煩骨突起

3 …側頭昌鱗

4...Tympanicum

5 ...Goniale

$6 \cdots$ 槌軟骨

$14 \cdots$ 外リンパ空

7 …砧軟骨 $19 \cdots$ 锞間切痕

15 …锞突起

$16 \cdots$ 舌下神経管

17 ... Sulcus basicochl. vent.

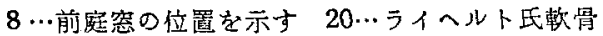

9 ...前逶部

10 ... Crista parotica

$11 \cdots$ 乳嘴突起の原基

$12 \cdots$ 單旁突起

$13 \cdots$ 頸静脈孔の位置を示す25…側頭翼

図 $240 \mathrm{~mm}$ 人胎児の頭蓋軟骨及骨（右下側面）

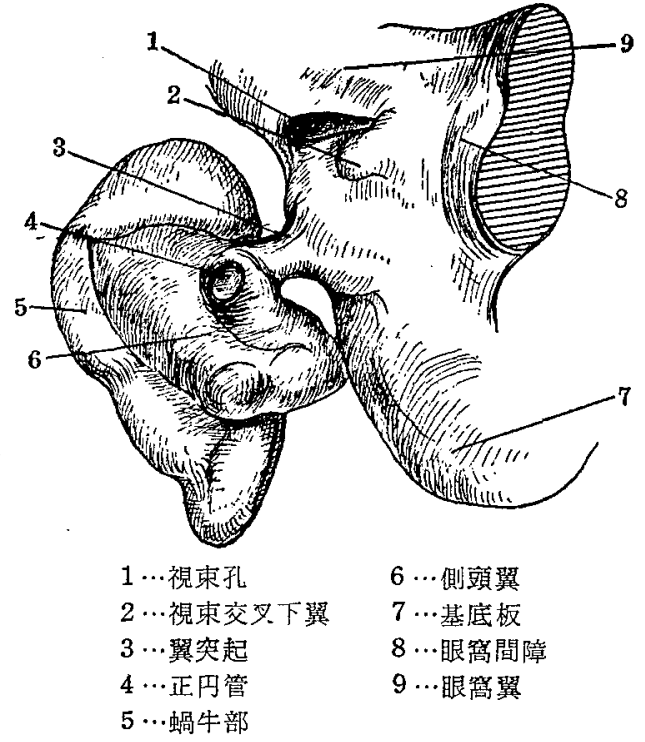

図 $340 \mathrm{~mm}$ 人胎児の側頭翼及堞形部（右前外側面）
叉下板でその 外側に視束交叉下翼 Ala hypochyasmatica が外方へ突出し，その上方に視束孔が開口す る。（図 14）その上方の部分は前外方へのびて眼筬翼 となり，その外側部から背外側突起 Proc. dorsolateralis が細長く突起する。下垂体简の外側部下より 飞蝶形体の外側部加翼突起 Proc. alaris が外方へ 後下よりに突出し，側頭翼 Ala tempolaris がこの突 起の外側方前方上りに大きくひろがる。側頭翼は手拳 状で下内方から外上方へとのびている。その略々中央 を正円管が貫通する。

後頭部 Regio occipitalis (図 1 , 図 2)

基底板の最後部汇当る底部から外方一続く外傊部及 後頭鱗から成り，外側部は後頭琹の部位で外下前方か ら内上後方へ舌下神経管により貫ぬかれる。後頭箱の 外側江綶旁突起 Proc. paracondyl. を热める。

メッケル氏軟骨 Meckel's cartilages（図 1，図 2, 図 4, 図 12 , 図 13, 図 14)

メッケル氏軟骨（以下メ氏軟骨之略す）以棒状，そ の横断面は円形で，その後端部は前庭部前端外側々在 ・る枮軟骨となり，蝸牛部から僅かの距離を保ってその 外側を前やや内下方へ伸び，溉頭翼の下方をよぎる。

ライヘルト氏軟骨 Reichert's cartilages (図 1, 図 2, 図 4, 図 12, 図 13, 図 14, 図 15)

ライヘルト氏軟骨（以下ラ氏軟骨と略す）は両端彎

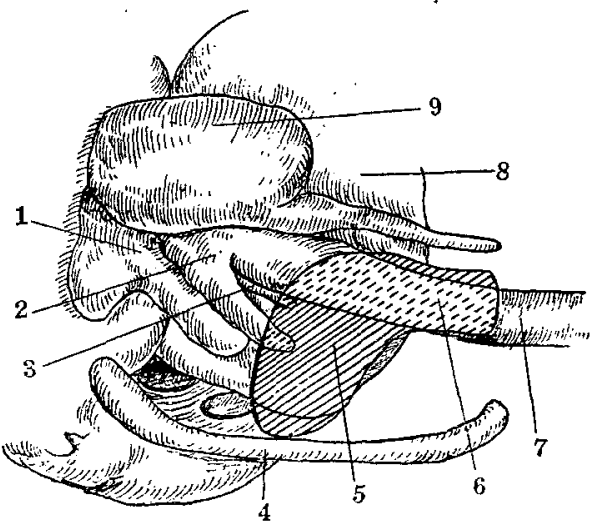
$1 \cdots$ 砧軟骨
6 …咽頭鼓室管
$2 \cdots$ 捾軟骨
$7 \cdots x ッ$ ‥乾骨
3...Tympanicum
$8 \ldots$ 蝸牛部
4 …ライヘト氏軟骨
$9 \cdots$ 側頭骨䚬
5 …鼓室

図 $440 \mathrm{~mm}$ 人胎児の咽頭鼓室管亚飞鼓

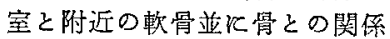

曲し、全長略々同一の太さで,その横断面は円形の細い 軟骨棒である。後端桬曲部の後方には Crista paroti$\mathbf{c a}$,前方には靖静脈孔があり，その後端は Crista paro- 
$-34-(892)$

tica の下前部江密接する。能旁突起の外上方, 蝸牛部 の下面をと礼等と嚾かの距離を陆て，前や入内下方へ 伸び，次いで㿠牛部から離れて乍らメ氏䎶骨に接近し，

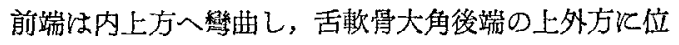
犆する。

舌颙骨，甲状軟骨 (図 12)

5氏軟骨前端の内下方飞在る舌軟骨大角と甲状軟骨 上角とは未だ連続しているが，両者は前後の方向略 々平行し，両者の移行部に当る部分の外側に小隆起を 誌める。

鼓室小軟骨（図 1，図 2, 図 4, 図 15)

檤軟骨はメ氏軟骨の後端部で，その小頭と柄とは外 万へ同しょうに傾斜していて，後者の下端はPromunturium 飞接している。砧軟骨は椎軟骨の後側外面に 緊密江接着し，同時江鼓室蓋の下側外面飞も接する。 短脚は後下方へ短く，長御は前下内方へ向つて長く伸 びていて，長脚下端内側飞鐙軟骨が接する。鐙軟骨は 略々環状で前庭慧中に在り，環は傾斜してと先の上部が 内方飞位置し，先の孔の軸は左右軸佂一致する。

骨

唄頭骨鱗 Squamosum（図 1, 図 2, 図 4, 図 12, 図 13, 図 14, 図 15)

鼓室小軟骨の外側出つて扇状の扁平骨と棒状の䅡 骨突起との 2 部分からなり，扁平骨の前は内方，後は 外方江少乙傾き，上，下雨側緑少少し内方攀曲して いる。煩骨突起はその前下側部につよ゙き，メ氏軟骨の 外上內の位置で，突起前端估側頭翼の外方，煩骨側頭 突起後端接近している。

Goniale (図 2, 図 14)

短い扁平の小針状骨で氐軟骨後端部内下面密接 平行する。艺の後端は棺軟骨の内側前部に在る。

Tympanicum (図 2, 図 14)

Gonialeより大きい扁平細長の骨でその外下前方K 位置し，メ氏軟骨の下倒面倿近している。Tympanicum の後端は Goniale の後端上り前方に終る。

下影情（図 1, 図 2, 図 12, 図 13)

メ氏軟骨の外側部淁する細長い板状の骨で，その 後端江側頭骨䚬煩骨哭起の起始部前下方に終る。筋突 起，関節突起の区別は不明瞭ではあるが，将来筋突起 となると思われる部分が特外方へ傾斜している。下

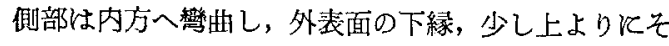
の長軸沃一致する簬がある。

翼突内側板 medial pterygoid plate

側頭翼の前側部内方にこの板の後端部を認める。
口蓝骨（図 12）

翼突内側板の下側汇ワ㥺情の錐体乫起後端を諗め る。

筋

咬筋（図12）下㑟骨の後部外僛にある。上部々側頭 骨䚬煩骨突起及规号側頭突起, 下部は下顎骨の上縁及 外側面江接乙，筇瀻維は後部では内，中，外の 3 周, 前部では後部の中，外の 2 㜿がー緒になつて外周とな っている。

側頭笳 (図 12, 図 13, 図 14, 図 15) 後方性側頭 骨䚢の上よりから前方は傊頭翼の外方，眼窩の外やや 下方功たつて広範国阮がる屚平の筋で，下部は下

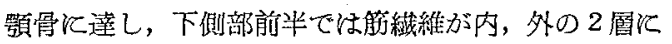
分れ，内屏は下颚骨の内側，中央部炕達している。

外側翼突筋（図12）略々三角形の筋で側頭筋，下類 骨，内側翼突筋，側頭翼，又民軟骨等江上つて园京 れ，後部は下钼骨の関節突起を生ずべき部位の内側部 飞接し，前部は上，下の 2 頭々分㮁，上方の小頭側 頭翼の前外側，下方の大頭は小頭より前方でその前端 は翼突内側板後端の外側江在る。

内側翼乫筋（図12）×氐靯骨の内湖，側頭筋前部の 内側江在る外側翼突筋の内倗，口蓋帆張筋の外側飞亦 つて上下の方向《起り，上部外側㕠突筋上口蓋帆张 筋との間に介在し，翼突内側板の後の位置を占め，下 部は 2 頭に分れ，外側頭はメ氏靯骨，内側頭は下影骨 下縁接している。

胸鎖乳突筋（図 12，図 13, 図 14, 図 15) 細長い 筋で，頚部の外側部を上後方へと漸次細くなり，留て 3ケの筋束となつて前庭部軟骨の外下方で終る。

影二亚笳後腹（図 12，図 13，図 14，図 15）細長 〈，全長亏氏軟骨飞平行する。後端は乳嘴突起原基飞 接し, 前や」内下方へ向い, 始めはラ氏軟骨の外側飞 接しているが，除々にとの下側位置を変劣乍らこれ から離れて，次第に細くなり，本筋とう氏軟骨との闑 飞䒱突舌骨筋が介在し，この筋の下側から外側飞出て ラ氏軟骨前端加ら離れる。かくて外项動眽の外側を通 つ，茎乫舌骨筋之共飞活軟骨大角の前端外側部淁 近して終る。蔆㔖舌骨筋（図 12，図 13）领二腹筋後 腹と共にラ氏軟骨の下側々略々これと平行する細長い 筋で, 後端は茎突咽頭筋後端の前方に在る。ラ氏軟㖊 と䫑二腹筋後腹との間をラ氏軟骨飞接し怎号前や」内 下方へと舌軟骨大角の外側部江終る。

頭長筋 (図13) 細長い筋で第一，第二頸椎の前外側 を後内上方へ问うが，第一新椎直上で上内方へ向を変 
方, 蛤牛前部の内側, 基底板の下外側部々終る。禁曲 部に絞れ加むる。

舌骨舌筋（図12）舌軟骨大角の上外側炕接し，蓬突 舌骨筋附着の内側《在る。

茎突舌筋（図12）５氏軟骨前端警曲部の上外側飞接 し，内側翼乫筋下端の内方を前や」内方へのびる。

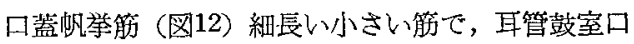
の直下から目管飞平行して前内方へ向い，耳管咽頭口 隆起の下を通つて，頭咽頭筋の内側より上方の位置で 口蓋汇達する。

口蓋帆張筋（図 12） 口蓋帆挙筋より大きく長い筋 で，その横断面は後部では一辺が四管の外側壁代平行 する三角形，前部では卵円形である。後端は耳神経節 と耳管との間，口蓋帆挙筋後端の前上外方にある。内 側翼突筋上部と耳管との間を前内下方へ伸びて，耳管 加ら雜れ，内側翼突筋と口蓝骨との間道する。

茥突咽頭筋（図 13, 図 14) 細辰い筋で, 後端は荎 突舌骨筋の後方, ラ氏赖骨の内側飞接し, 略々この軟 骨に平行し，その前端部の内や小前下方の位置で外方 から舌咦頭筋化大る。

頭咽頭筋，舌骨咽頭筋，知頭咽顽筋（図12）本朌群

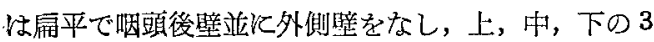
.層となって前後江向5。

鼓膜張筋（図 14，図 15）横断面が円形心細長、筋 で，枹软骨唡前端附近の内側部から内上方へ一寸伸び てすぐ前方へ曲り，メ氏軟骨と螖牛部の外側との間を 後者倿し年ら鼓室のすぐ上飞沿うて前内方へ向い， 耳管鼓室口の近くで耳神経節周图の組織の下面の部分 洛る。

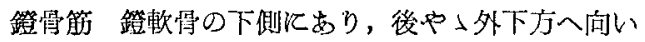
顔面神経の内側を通つて乳㗪突起原基の内側飞達す る。

耳管前に鼓空（図 4, 図 12，図 13，図 14，図15） Tubotympanalrohr汸前方の耳管と後方の鼓室とを区

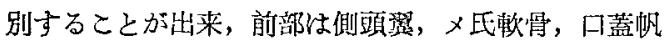
張筋, 口蓋帆举筋等, 後部は螖牛部, 又氏軟骨, 5氏 軟骨等によつて囲まれ，(図 12）前端の耳管咽頭口は 咽顽鼠部外側壁の後上部（口蓋骨錐体突起の下方）飞 開口し, 後端々 Promunturium D外側飞在る。Tubo tympanalrohr の軸怯咽磌口から外後方へ向方水平線 でる。Tubotympalrohr の形態及耳管浃の位圆（図 5) から推定すると耳管と鼓室との境, 即, 耳管鼓室 口は内頸動脈のすぐ外側の位置にあって両者の長さの 此恪略々 $2: 3$ である。
咽頭口から始まる耳管はその横断面が略々楕円形の 短管で，咽頭口から始まつた許りの部分では外側塈が 外方へ多少膨隆しているが，耳管峡附近から鼓室の方 へかけては下壁が平坦である。上下及左右径注㸶頭口 $(0.6 \mathrm{~mm}, 0.18 \mathrm{~mm})$, 最峡部, 即, 耳管陕 $(0.4 \mathrm{~mm}$, $0.12 \mathrm{~mm})$, 鼓室口 $(0.54 \mathrm{~mm}, 0.24 \mathrm{~mm})$ で，呐頭口 から次第に狭くなる。耳篦の咽頭口隆起恃認められる （図12）が，全〉結締織珄で耳管軟骨の原基や腺組織 は諗められない。

鼓室腔は内外洴扁平な不定形（図 5)で，内溉壁は 蛙牛部外側壁の形態行従つて彎曲乙，中央部任内腔極
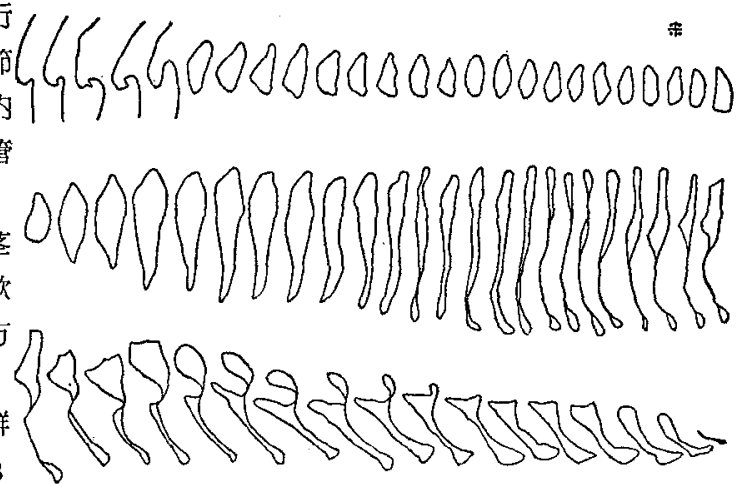

図 $540 \mathrm{~mm}$ 人胎児の Tubotympanalrohrの前 頭断の連続

第 1 列は耳管，鸽 1 列左端《耳管咽頭口， 第 2,3 列は鼓室, ※朾は耳管狭である。

めて㹨く，後側より外上後方加栍軟骨柄加突出し ている。上下径の最大径は中央の少しく前よりで(1.76 $\mathrm{mm}$ ), 内外径の最大部怯微方柏軟骨柄の突出の上部 である。これに対し前後の径は切片の数から略算して $1.3 \mathrm{~mm}$ 程である。外上方から树軟骨柄の先端何つ て伸びている外耳道には数ヶの外耳道軟骨原基が出来 ているが，この外耳道の宣端は下方へ曲り，鼓室腔底 部の高さ近くに達する。この彎曲した部分と豉室腔と

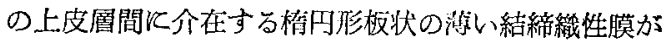
鼓膜原基である。

血管

動脈

内頚動脈（図 6, 図 13）舌軟骨大角之甲状軟骨上角

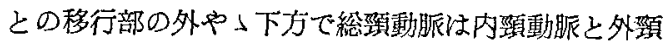

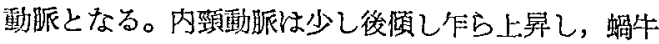

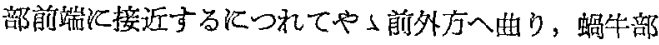
の前端と耳管陕部附近との間を前者に接して上昇す る。次いで後方へ曲り乍ら翼突起の後側を通過し，や $\checkmark$ 前方へ戻つて，小翼のすぐ後側を通り，脳膜に達乙 


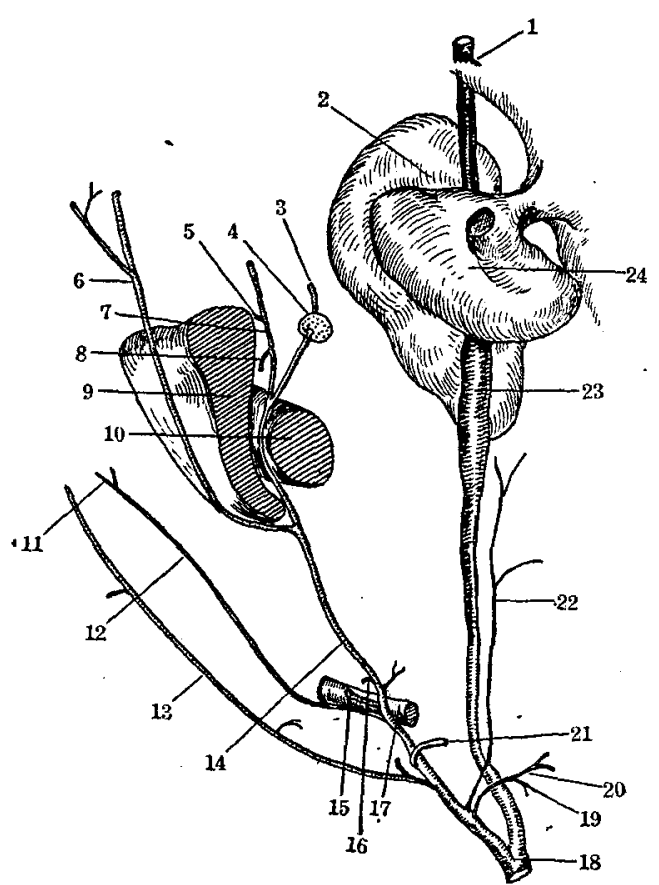

$1 \cdots$ 眼動脈

$2 \cdots$ 蝓牛部

3 …中硬膜動脈

4...耳耳神経節

5 …咬筋動眽

6 …浅側頭動脈

$7 \cdots$ 顎動脈

8 …下崡槽動㟲

9 ...下顎骨

$10 \cdots メ ッ ケ ル 氏$ 軟骨

$11 \cdots$ 荃乳突孔動脈

$12 \cdots$ 耳分後動脈
13…後頭動脈
$14 \cdots$ 外缜動眽
15‥顔面動脤
16…胸銧乳突筋動脈
17 ‥ライヘルト氏軟骨
$18 \cdots$ 総頊動脈
$19 \cdots$ 上喉頭動脈
$20 \cdots$ 上甲状腺動脈
21 ...舌動脈
$22 \cdots$ 上行哂頭動脈
$23 \cdots$ 内頚動羱
$24 \cdots$ 側顥翼

図 6 $40 \mathrm{~mm}$ 人胎児の総頚動脈の分枝（前面）

てこれを貫き外上方へ向を変劣る。内頸動脈は総頚動 脈加ら分枝して後次第に太くなり，耳管と蝛牛部との 間を通る部分が最も太い。

眼動脈（図12）内頸動脈吕脳膜を貫く直ぐ下㑡で前 や小内方へ向つてその前暨加占眼動脈分分枝する。眼 動眽は先づ脳膜中を通り，乙れから出ると視束交叉下 翼の外方, 視束の下, 動眼神経の外側走通つて眼窝内 几向5。

外頚動脈（図13）総政動眽から分枝すると内镇動脈 程でななが少し後傾し乍ら上や」外方へ向い，内頸 動眽から遠ざかつてラ氏軟骨前端少し後よりの下縁に 達し, ラ氏軟骨の外側から後方へ曲り, 再び上や」外 方へ向らが，いくらか内方へ曲り乍らメ氏軟骨と下類

骨後端部との間隙の下端に達し，㐋こで浅側頭動脈と 顎動脈とに分れる。

上甲状腺動脈（図 12，図 13）外頙動脈の始部前内; 側壁から前内上方へ向つて上甲状腺動脈吕出る。次い で前内上方加前や小内方へ向変变，甲状軟骨上角 の直ぐ外側を走る。こ〉て上㑨頭動脈を分枝する。

上行咽頭動脈（図13）上甲状腺動脈の分枝部之略々 同じ高さで，内側壁から上や」後方へ向つて方枝し， 内頸動眽の内側を僅かの間隔で平行し，その起始部か ら蝸牛部の高さに達する。での略々中間で内外の 2 枝 に分れる。内側枝は咽頭枝であつて，分れて後内や」

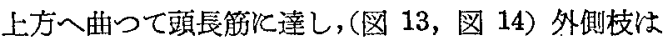
後や上上方へ向い，上行する間以内頸動脈神経内側枝 そ接近するがまた遠ざかり，終枝分れる。1枝は舌 下神経管の中へ入り，他の 1 枝はとのま上上行して下 鼓室動脈となる。

後頚動脈（図 6, 図13，図 14，図 15）前の2枝 から少し離れて徣側壁から後上や小外方へ向つて分枝 し，ラ氏軟骨の下方てこれと平行して走り，始め旗

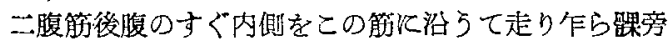
突起外僛飞接するが，次いでこの筋から濑次離れ，前 庭部の外下側を通つて後頭部へ向 5。途中 3 分枝, 即, 乳突枝, 耳介枝, 下向枝之思われるるのが出てい る。

舌動脈（図 6, 図 12）. 後頭動脈分枝部の直上で, 前内側壁から, 前内や上上方へ向つて分枝し, 舌軟骨 大角の上方を走る。

耳介後動脈（図 6, 図 13, 図 14, 図 15) 外頚動 脈がラ氏軟骨の外側を迁湎する直前，外側壁から铚や 小外方へ向つて分枝し，軟骨の外側沿万て走り乍ら 次第に关の上側飞出て，内外の 2 枝に分れる。内側枝 は間も無く消失するが，外側枝は茎乳突孔動脈であつ て，5氏軟骨後端を離れ，顔面神経の直ぐ内側江沿う。

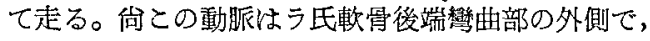
内方へ向つて極く細い小分枝を出す。

顔面動脈（図 6，図 12）外頸動脈がラ氏軟骨外側 を过廷する部分で，前照加前や上上方へ向つて分 枝し，下顎骨下縁化接近する。途中外方へ向５1分枝 がある。

浅側頭動脈 (図 6, 図 13, 図 14) 下䪽骨後端の外 側倿乙乍的上中小後方へ向い，側頭骨及乞の搷骨， 突起外㒋沿5て前方へ向を変克，多〈の屈曲分枝儿 より側頭筋の外方佁広く分布する。

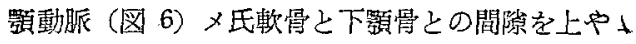


前方へ向い，次いで強く前方へ曲り，靯管上縁の高さ で，下䜹骨と外側翼突筋との間を上や小前方へ走り， 下影骨内側塈飞沿って上行，次いで側頭筋と外側翼突 筋との間を内上走する。

中硬膜動脈（図 6, 図 13, 図 14, 図 15）顴動脈 の前方へ強く曲る部分の上壁から上内方へ向つて分枝 する。この動眽はメ氏軟骨の真上で後や」上方へ向を 変え，耳分側頭神経の中を通り，さらにその後上方で 耳神経節の外側部を貫く。次いで後方へ伸びる耳神経 節の外㑡突起外側飞沿つて後方へ向い，上錐体静脈洞 とメ氏軟骨との略々中間を後方へ少し走り，弧を描い て外上方一向い，上錐体静脈洞の外上側壁に接近し， こょで 2 枝炕尔れる。その 1 枝は静脈洞の外上側で後 方へ曲り作らこれから醀れ，他の 1 枝は分枝すると直 ぐ前上方へ之静脈洞から遠ざかる。

下歯槽動脈（図 6, 図 12）瀕動脈前壁加占前方へ 河つて出る下歯槽動脈は, 下歯槽神経の外側飞沿い, ×氏軟骨の上側を前や小方へ走る。

下歯槽動脈の分枝部の直ぐ上で，顎動脈後垶から下 硕骨の内側壁沿沿つて後方へ向う小分枝があるが，深 耳介動脈々も前鼓室動脈々も決定出来ない。台顔面動 脈分枝部の面上で内，外向了2小動脈が分れている が、外へ向いているものは胸鎖乳突筋動脈と思われる。

鐙軟骨輪の中前額面汇一致乙乍ら外や上上方から 内や人下方へと一直線の紐短の血管がある。乙れは他 の血管と連絡の無い拓立したもので，萎縮しつ」かる A. stapedialis と推定される。

\section{静眽}

横静眽洞（図 7) 前庭部後端内側を内下方へ向い， 内リンパ孔の開口の下方で前や」内方へ向を変え，舌 晒神経, 迷走神経, 副神経等の外僛の位置を占め, 内 预静脈江移行する。乙の静脈洞は太く，その横断面は 後部では略々三角形であるが，前部では次第に四角形 となる。前庭部後端の後上方で上錐体静脈洞汇連絡す ๖。

海綿静脈洞（図 7, 図 13, 図 14）大きく複雑不正 形の静脈洞で後部が拡がり，内側に蝶形軟骨体部及卜 ルコ鞍，外側飞蝸牛部，半月神経節，上側飞小翼，下 側江蜻牛部が在つて，内転神経はこの静眽洞の略々中 央部を前後化實き，内頸動脈はその前部を賁く。

眼静脈 海綿静脈洞の前部に連絡し，静脈洞の一部 が前方へ乫出し，その外側よりと眼静眽が発達する。

蝶頭頂静脈洞，海綿静脈洞の前上部飞連絡する。 下錐静眽洞，海綿静眽洞の後下部汇連絡する。

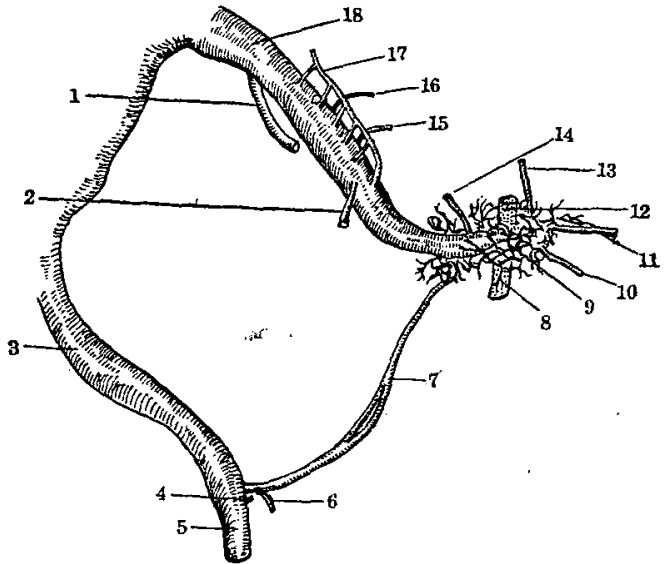

1…迷路静脏

$11 \cdots$ 眼静脈

$2 \cdots$ 鼓膜張筋之蝸牛部と口 間の静脈からの枝

$12 \cdots$ 内頚動脈

$3 \cdots$ 横静脈洞

$4 \cdots$ 蝸牛小管静脈

$5 \cdots$ 内頸静脈

6 ...Sulcus basicochl. vent. の静脈網からの枝

$7 \ldots$ 下錐体静脈洞

$8 \cdots$ 内頚静脈蕞

9 ...海綿静脈洞

$10 \cdots$ 蝶頚頂静服洞

$13 \cdots$ 海綿間静脈洞

$14 \cdots$ 前庭部の内方からの 静脈

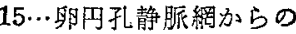
枝

$16 \cdots$ 半月神経節の周四の 静脈網汃らの枝

17…中硬膜静脈

$18 \cdots$ 上錐体静脤洞

図 $740 \mathrm{~mm}$ 人胎児の硬膜静脈洞（外㑡面）

海綿間静脈洞（図 7, 図 13）下垂体と下垂体窝と の間の間隙に在つて, 左右の海綿静脈洞の前内部を結 び，中央約三分の一の距離が一条となり，下垂体から 数策の血流がこの静脈洞比入る。

上錐体静脈洞（図 7, 図 13，図 14，図 15）頗る 太く, 海綿静脈洞の前外部加翼突起後側に接して外 や小下方へ向い，蝸牛部前端外部之三叉神経か 3 尔枝 飞分れようとする部分との間，次いで蝸牛部と半月神 経節との間を通り，や」太くなる。半月神経外側でや 1 上方へ桘軟骨後端上方で後方へ向を変え，前庭部を 少し離れたところをや小内方へ頙き乍ら後走，その後 上方て横静脈洞の前壁汇連絡する。

内项静脈裴 Plexus venosus caroticus internus （図 7, 図 13）内莖動脈の周囲の静脈叢 から上上錐体 静脈洞の下側学外や」下後走する 1 分枝があつて，こ の洞が半月神経節下側を通る部分の下壁に入る。この 分枝加大大浅錐体神経江接して後や小外下走する小分 枝があり，始め沉神経の内側在るが，次いでそ の下側から外側へ廹り，これる後方で錐体静脈洞下 壁飞入る。 
$-38-(896)$

沿上錐休静脈洞炕入る静脈汇（図14）前庭部内分か ら起つて前や小外上走して螖牛部の上後端飞達し，海 綿静脈洞の外側から蝸牛部之半月神経節之の間を経 て, 上雓体静脈洞の内垶汇入るすの゙ある。この静脈 は海綿静脈洞の外側を通過する部分でこれと連絡して W。

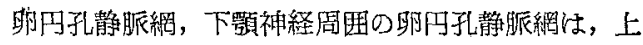
錐体静脈洞が半月神経節の外僛飞出る部分飞， 3 条こ れ汇連絡する。この静脈網は下疑神経の走行に従い頭

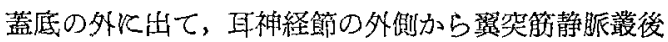
部連絡する。

中硬膜静脈 (図 13, 図 14, 図 15) 中硬膜動脈江 2 条以上を西つて随伴する中硬膜静脈は，先の動脈が

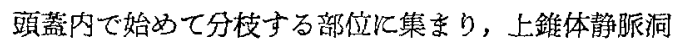

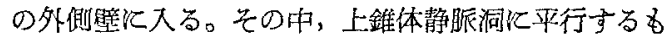
のがあつて，上記連絡点の後で 5 条の洞一の咖合枝を 出している。

鼓膜張筋と蝠牛部との間の位置注ずる数条の静眽 は，この筋の起始部内側集まり，上方一向い急に太 くなり，上錐体静跟洞の下壁汇入る。

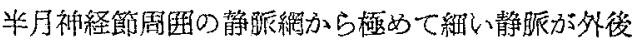
方へ向つて出て, 前庭部前端の上方で上錐体静脈洞の 上内壁に入る。

迷路静脈 内耳孔加ら出ると, 後内方一南い, 迁明 し乍ら脳膜学貫いて上錐体静脈洞の内壁に入る。

下錐体静蝗洞（图 7 ，図 14，図 15）海綿静脈洞の 後下外部加䖮牛部内側飞接して下走，後や小外下万 一向孝变光て Sulcus basicochl. dors. 江沿うて起り， その後端から occipitococochl. notch 通り，頸静 脈孔の中で内頸静脈の内壁便絡する。この静脈洞の 中央部は 2 条汇分れている。

Sulcus basicochl. vent. 㳊沿亏て発生している静

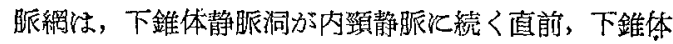
静脈洞《入る。この静脈網は舌下神経管静脈網にも続 いている。

蝶頭顶静脈洞（図14)小翼突起の外後方加与内前方 へ向い，小翼後縁の下側江沿了て内下方へ走り，海綿

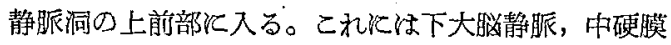
静眽からの吻合がある。

内頙静脈（図 8, 図 13, 図 14, 図 15) 頙静脈孔 の中で舌㽖神経，迷走神経，副神経等の外側の位置を 占める静脈で前や」外下方へ向い乍ら孔出て内攻動

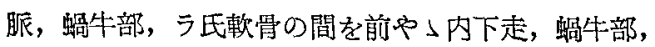
ラ氏赖骨から次第に離れ，頭長筋起始部外溉て急に下

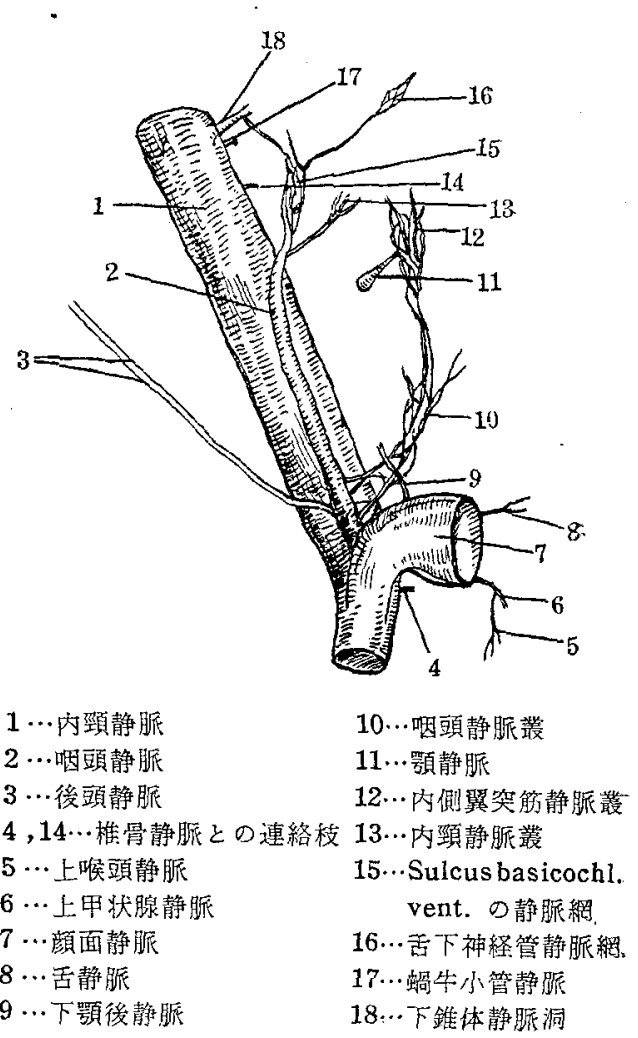

図 $840 \mathrm{~mm}$ 人胎拀の内頸静脈の連絡枝（前面）

万へ向変える。新静脈球《明らかでない。

蝸牛小管静脈（図 7, 図 8, 図 15) 䫓静脈孔の中， 下鍂体静脈洞が入るすぐ前方で，内鲗静脈内壁仅入 る。

椎骨静脈（図 8) 頚静脈孔の直下で内新静脈の下㷱 そ，またその下方頭長笳起始部の外㑡ではとの内壁に 各々椎骨静脈吕ら交通枝が入る。

颜面静眽（図 8, 図 12）太い静眽で舌丳骨大角の 外側学後や」内下方へ向い，その後端外側で急《下外 方へ曲り細くなつて内頸動脈の前を通り，その外側て 内頸静脈上壁に入る。

下頻後静脈 (図 8 , 図 9 ) 総側頭静脈 V. temporalis communis の内壁から 2 条の極好て紐い静眽が出 てたがらに合流して1条となり，幾多曲折を経乍ら下 や小前内走，ラ氏軟骨之茎突舌䯈筋之の閒を通り，外 愐動脈队側で顔面静脈の後壁に入る。この静脈々呐頭， 静眽との間沕合がある。

舌静脈（図 8, 図 12）舌軟骨大角上㑡を舌咽神経 の上及下接して後走，合流して1条となり，顔面静 眽内壁汉入。 
上甲状腺静脈（図 8，図 12）甲状軟骨上角外側を 後や」上方へ向う 3 条の上甲状腺静脈泟, 合流して 1 条となり，外方へ曲り，顔面静脈内壁淡入る。咽頭静 脈之の間化吻合がある。

咽頭静脈 (図 8, 困 13, 困 14) Sulcus basicochl. vent. の静脈網は，螖牛部下面之節状神経節との間， 内頸動脈の外側を前や小内下走, 内頙静脈の内側飞沿 与て下る加，下端は次第にての前面に出て顔面静脈の 後壁汇入る。Sulcus basicochl. vent. の静脈網咕舌 下神経管静脈網及下錐体静眽洞上連絡するこ上は前保 述べた通りであるが，咽頭静脈汇は下顎後静脈の他飞 次の吻合がある。即, 内钼静脈加らの静脈は sphenocochl. notch, Sulcus basicochl. vent. を走り, 咽 頭静脈の起始部でこれに入り, 後頭動脈の上下に平行 する 2 条の後頭静脈は，乙の動脈が咽頭静眽を横切る 部分でこれ炕入り，内側翼突筋の内側，口蓋帆張筋，

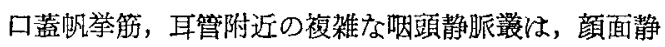

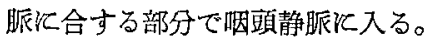

外浅频静脈(図 9, 図 12, 図 13) 鼓室前部の外側

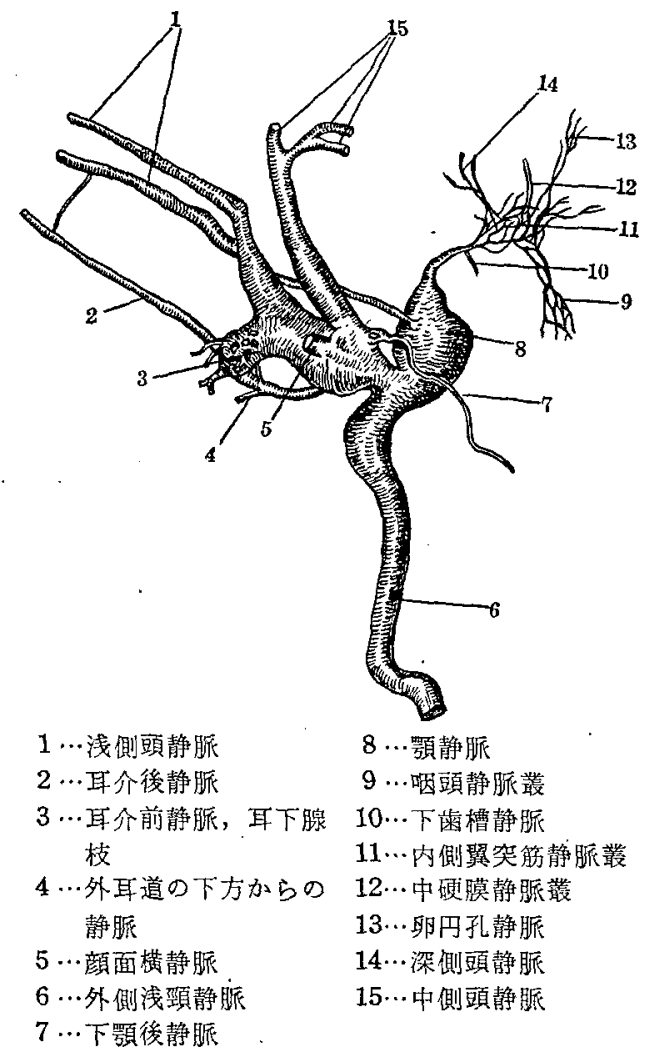

図 $940 \mathrm{~mm}$ 人胎児の外側浅贸静脈 の連絡枝 (前面)
で総側頭静脈と内䫑静脈とが合して外側线頸静脈とな り，始め外下方，次いで前や小下走，胸鎖乳乫筋外側 洋し，細くなつてとの筋汇沿い乍方直線状に走り， 嵃面静脈の外, 前方上りの位狊で下方へ向を変え, 胸 鎖乳突筋から離れる。

総側頭静脈（図 9，図 13）下影骨後端外側の下， 前方よりで浅側頭静脈之中側頭静脈とが合して太い総 側頭静脈となり，下や小内走ラ氏軟骨上方で外浅頙静 脈江移行する。

浅側頭静脈（図 9, 図 13, 図 14, 図 15) 側頭筋 の表面の結締織圂から集京り，外耳道入口部の上方に

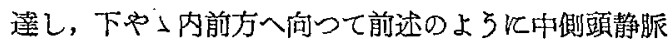
と合し，総側頭静脈となる。浅側頭静脈は顎静脈へも 連絡する。向浅側頭静脈之耳介後静脈との間には砧軟 骨外側老通る極めて細い交通枝がある。外耳道周团及 耳下腺中から出る静脈で形成她られる極めて複雑な耳 介前静脈及耳下腙枝注，浅側頭静脈上中側頭静脈之が 合する少し前に前者の外壁に入る。向此等は耳介後静 脈上の間に吻合がある。

中側頭静眽（図 9, 図 13）側頭筋の前部から集玉 り，後方へ向い，乙の筋の外表面炕出て1条となり， 眼窝の上外方から来る静脈を入れて下や小内方へ向を 変光，側頭筋後部から来る静脈を古せて浅側頭静脈 と合し，総側頭静脈となる。

顔面横静脈（図 9, 図 13）咬筋の外表面に沿亏て 後方へ向い，総側頭静眽前壁飞人る。

耳介後静脈（図 9, 図 14, 図 15) 前庭部外側から 集まり乍ら前方下よりと走り，ラ氏軟骨に站えでその 外側を通り，総側頭静眽後垶に入る。途中外耳道の下 方から来る静眽を合せ，耳介前静眽とす吻合がある。

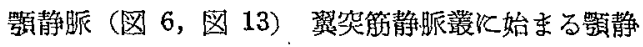

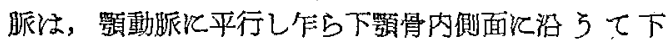

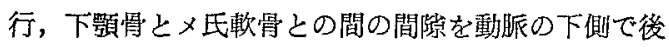
下走, 間鄚を出ると動脈の内側出て急飞著しく太く

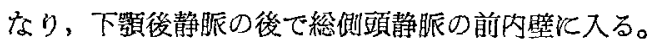
下函槽動脈の外側々平行して後走する下宷槽静脈は，

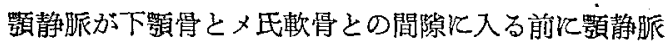
の前壁に入る。（図 9，図 12）翼突筋静眽㒈は外側翼 突笳の内外雨側, 内側翼笑筋の内側飞㹡がる複雑な静 眽網で, 耳神経節附近から中硬膜動脈の内側に平行す

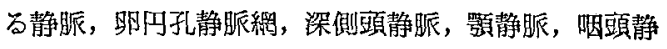
眽灇等と連絡している。

\section{神経}

動眼神経（図 12，図 13，図 14，図 15）三叉神経 
$-40-(898)$

の上万を前や小外方へ向い，脳膜を曾き，半月神程節

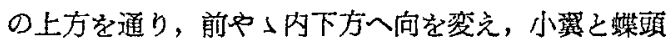
頂静脈洞との閻を走り，内頸動脈の外側から視束（視 束視束孔を前やや外下方二向５）の下側飞出て 3 枝 汇分れる。蝶頭頂静脈洞の上側を通る少し後方で内外

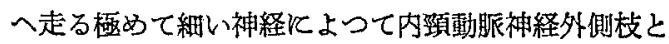
連絡し，この洞の上側を過ぎると直ぐ既神経と連絡す る。

滑車神経（図 12，図 13，図 14，図 15）動腿神経 の後方で脳膜を貫き，この神経の外や」上方を平行し て走り，蝶頭頂静脈洞の下㑡を通つて次第汇前頭神経 に接近，遂にこの神経との識別が困難となるが，躲て 視束の外側でこの神経の内方に出る。蝶頭頂静脈洞の 直ぐ後側及下側で眼神経と連絡する。

三叉神経（図 11，図 12，図 13，図14）略々扁平 の太い Portio major ととの内側の細い Portio minor とは前庭部の内上方を前やや下方へ平行し, 蝸牛部の 上，後端に達し，脳膜を貫き，Portio major は海綿

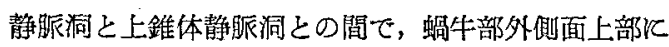
接する大きい半月神経節沉入り，上鉝体静脈洞の上て 眼神経，上颚神経，下影神経化分れる。内側のPortio minor Portio major 々䗁牛部々の間, 半月神経節 と蝸牛部之の閪を外や」前下方へ向い，次いで外前方 へ向を変克，半月神経節の下，上錐体静眽洞の上を前 や子外方へ走り，次いで静脈洞加ら離れ，上預神経の 下側变外や」下方へ斜飞通過し，耳神経節の直ぐ上側 で内上方から下影神释泟入る。

眼神経 (図 12，図 13) 半月神経節上部加台前や」 内下方へ向い，動眼神経の下側を数ヶの神経束に分れ て走り，蝶頭頂静脈洞の下側を通過すると再び一つに なり，眼静眽の外側で添腺神経，前頭神経及界毛样体 神経行分礼, 眼神経と動眼神経, 前磌神経と外転神経 との間に各々交通枝がある。

上顎神経（図 10，図 12，図 13）半月神経節の中 程加前方へ向い，正円管を出ると内方へは口蓋神 経，外上方へは煩骨神経を分枝する。硬膜枝を捜した が見つからなかつた。口蓋神経は上䫑神経から分枝す ると直汇翼口蓋神経節の後外部に入り，神経節の中で 前方へ向を变克，一部分が 2 枝に分れるがすぐ合し て神経節の前下部加らその外江出て, 翼乫外側板の後 端外側を下方子外方へ向 万。頪骨神経は前外方へ向 い，その先は前方へ向万煩骨顔面神経上，外户」上万 へ向き側頭筋向向 5 煩骨側頭神経と飞分れる。

翼口蓋神経節 Ganglion pterygopalatinum（図10，
図 12)後方へ伸びる突起を有する不正形の神経節で

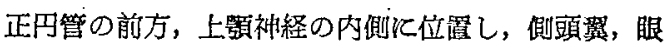

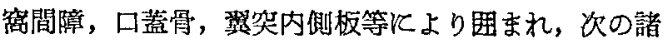
神経艻連絡している。

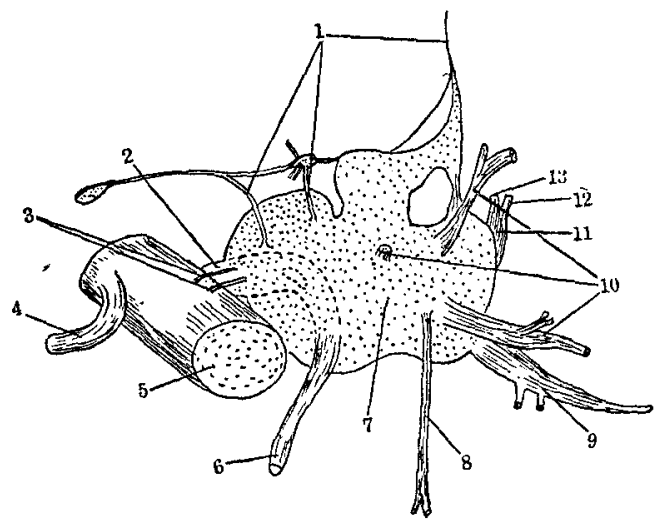

1 …眼登枝

$2,6 \cdots$ 口蓋神経

$8 \cdots$ 咽頚粘膜下飞至る神経

$3 \cdots$ 翼口蓄神経

$4 \cdots$ 僰神経

5 …上買神経

…鼻口蓝神経

$10 \cdots$ 外側後鼻枝, 中隔後鼻枝

11 …翼突管神経

図 $1040 \mathrm{~mm}$ 人胎胃の翼口蓋神経節（前面）

翼突管神経（図 10）大浅錐体神経と梁錐体神経と は側頭翼の内側面後端で翼突管神経となり，側頭翼に 接し乍ら前走, 側頭翼から離れ，後方から翼口蓋神経 節後内下部々入る。（図 10，図 14，図 15）大牫錐体 神経は顔面神経滕加与蝸牛部の外表面や」上側を前 走, 次第に蛤牛部から離れ, 内镇動脈の外側を通り, 側頭翼の内側面後端で翼突管神経となる。(図 13) 乙 の内頸動脈外側を通方部分以，内頚動脈神経外側枝加 ら細い神経瀻維が漸絡する。これとは別々内頸動脈神 経外側枝加方浅錐体神経江平行して走るのが深錐体 神経で，直に翼乫管神経となる。

口蓋神経（図 10，図 12）前述の如く翼口蓋神経節 の外側部害く。

翼口蓋神経（図 10）上噭神経と翼口蓋神経節外部 との間の細短の 2 吻合枝で口蓋神経の前に列ぶ。

眼容枝（図 10）神経節前上部加5外，中及内の細 い3 枝が上方へ向う。外側枝は 3 枝のうち最前方《あ つて上外方へ向い，上影神経の上方の眼窝下壁得す る神経細胞小集回炕入る。中側枝与上方へ向い，眼筬 下壁炕接する今令一のの神経細胞小集団に入り，乙の集 団加眼简下壁飞接して前方へ向 52 枝，外上方へ走 り外側枝と連絡する 1 枝, 内上方へ走り内側枝と連絡 
する1枝，眼窩下壁を通過して上外方へ向う1枝があ る。内側枝は神経節の後中央部から上方一向 5 。

外㑡後毁枝，中隔後舅枝（図 10）神経節の前内部 加前内や上上方へ向５2枝と，内や上下方へ向５1 枝とがあり，此等は外側後窈枝，中隔後鼻枝之推定さ れる。

奥口蓋神経（図 10，図 12）神経節の内下部加方内 下方へ向い，咽頭粘膜下に達すると急に細くなつて内 や上上方へ向を変え，眼窝間障の下側を反刘側の奥口 蓋神経江接近する。この神経の太い部分から細い2枝 が下や子前外方へ分枝し, 内側方の枝は呕頭粘膜下, 外側方の枝は耳管咽頭口附近上側に終る。

份以上の他飞神経節の前下内部から粘膜下飞出る若 干の神経瀻維を認める。

下顎神経（図11，図13，図14）半月神経節の下部汃 ら出て, 始めは上錐体静脈洞の上側飞接し, 前や」下 走, 耳神経節の直上で放加入る Portio minor を併せ，その内下側倿する耳神経節との間飞 3 ケの 物合枝があり，本幹忹次の諸神経を分枝する。

下顎神経起始部の外下㒋加ら上錐体静脈洞の上側江 接して外方へ硬膜枝を分枝し，乙れは上錐体静脈洞と メ氏軟骨との中間で後外上方へ曲り，上錐体静脈洞飞 略々平行して後外上庁一向万中硬膜動脈之列えで走 り，途中 1 細分枝老出す。上錐体静脈洞と $\times$ 氏軟骨と の中間, 方向の変る部分飞, 耳神経節から極めて細い 神経䋐維の吻合がある。

咬筋神経（図 11，図 12）本翰から外方へ向い，外 側翼突筋後端の上を走り，乙の筋の上端外部に接し'乍 ら咬筋神経と後深側頭神経とに分れる。

煩神経 (図 11, 図 12) 本幹から前や〉外方へ外側 翼笑筋の大頭と小頭との間を走り，終枝に牙れる。乞 の始まりの部分から直ちに 2 条の外側乵突筋神経を分 枝し，乙の 2 枝の中間.の位盕儿，煩神経と耳神経節と の間の物合がある。

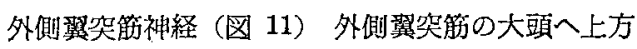
から，小頭へは前者の末梢で外方から，各及細い神経 が頝神経から分枝している。

内側翼突筋神経（図 11，図 12）鼓膜張筋神経，口 蓋帆張筋神経と一緒倿節神経の分枝部の反対側から 下や子前内方へ向い，直に耳神経節《入り，その略々 中央上りや入外側を通つて，下方から神経節の外化出 て, 内側翼突筋の後方加らとの筋の内側面飞沿 い走 り，との筋䏓入る。との神経は耳神経節を出る少し前 汇神経䌈胞との連絡を認め, そのすぐ末梢で枝膜張筋

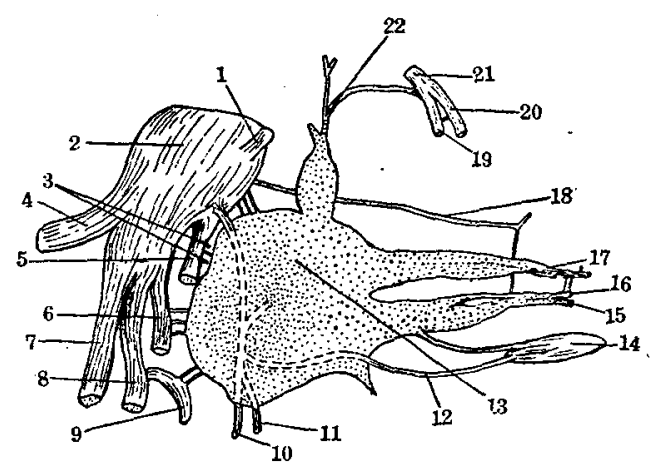

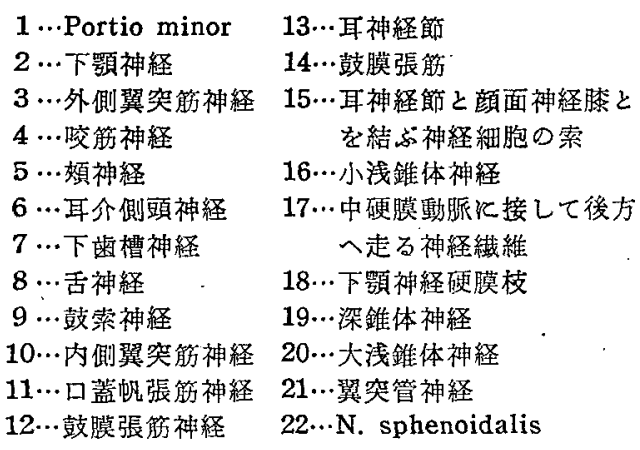

図 $1140 \mathrm{~mm}$ 人胎児の下買神経の分枝主 江耳神経節（前やや内侧）

神経，口蓋帆張筋神経に分れる。

鼓膜張笳神経（図 11，図 13）前述の如く耳神経節 加ら出る直前て内側翼突舫神経から分れ，後方へ曲り 乍ら神経節から出てその内下部の直下を後走, 前方か 、ら鼓膜張筋飞入る。

口蓋帆張筋神経（図 11）前者のすぐ末梢て内側翼 突筋神経から分れ，耳神経節下部の表面近くをや小内 上方へ，次いで下方へ曲り乍ら耳神経節から出て，口 蓋帆張筋の直ぐ外側を少し後走, 归を描いて外方から 前方へ向を変え，下方加らとの筋㑢する。

耳介㑡頭神経（図 11，13図）前記諸神経を导枝し た後, 少し下方から分校し, 外側翼突筋内側面倿し 乍ら下や小外方へ向い，こ小を中硬膜動脈で貫奴かれ る。次いて下方へ中硬膜動脈の後側に出て, これに平 行し乍ら下顎骨とメ氏軟骨との間を通り，下顎骨下縁 を外方へ廻り, 上外户上後方へ向を变元, 浅側頭動眽 の外側をこれと平行し作ら走る。

下歯槽神経（図12，图13) 下頍神経の終枝の一で， ×氏軟骨の上をこれと平行し乍占前や小内下走，×氏

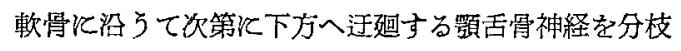
する。

舌神経（図 11, 図 12) 舌神経は分枝後直ぐ後方か 
ら鼓索神経がこれに入り，メ氏軟骨の上溉で下曾槽神

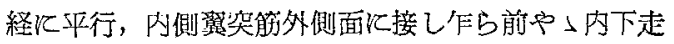
ta。

耳神経節 Ganglion oticum（図 11，図 13)

神経節上外部に下㩆神経が接し, 前後の方向江細長 く, 前後径は $(1.26 \mathrm{~mm})$, 最大部は内项勤脈外側の少 乙後よりで上下, 左右径恪各々 $(0.52 \mathrm{~mm}),(0.66 \mathrm{~mm})$ である。上錐体静脈洞，入氏軟骨，蝸牛部の形成する 三角の略々中央部位置し，後方へ内外並ぶ2 ケの 乫起が出て居り，この内侧突起神経細胞性の細い索 となり，同じくとの乫起から出る小浅錐体神経の外側 飞密接したま子後方へと顔画神経䐂儿連絡する。内 㑡突起と外側突起との間汇細い神経瀻維の連絡を認め る。中硬膜動眽が神経節の外部を前後化貫き，外倒突起 飞沿うて後走する。耳神経節の上飞は側頭翼, 上錐体 静脈洞，下顎神経，下にはメ氏軟骨，耳管，鼓室腔， 外飞は下影神経, 外側翼突筋, 内飞は蜡牛部前部があ る。この耳神経節には次の諸神経が連絡している。

下顎神経 下額神経內部之耳神経節上部之の間に 3 条の畍合があり，ての3枝のうち中枢側が最も太く， 中央が最子緗い。

煩神経 2 条の外側翼突筋神経が出ている部分の中 䦭の頝神経と耳神経節前外部と。間に斜走する吻合が ある。

翼突管神経 翼突管神経が大浅錐体神経と深錐体神 経上飞分机る部分上耳神経節上部门笑起との間沟合 がする。この神経は Rauber-Kopsch (1940) KN. sphenoidalis と記載されてるるが，耳神経節の上方へ の突起が翼突起外端の下や」外方で 2 枝て分れ，内方 へ曲る枝は僅汃 2 分して裂突管神経に入り，上方へ 向 万枝以翼突起外方で 2 分して終る。

小浅錐体神経 顔面神経滕前端汇連絡する鼓室神経 から移行する小浅錐体神経は，顔面神経膝と耳神経節 と党結ぶ神経緗胞索の内側汇密接して前走, 耳神経節 の後方へ伸びる内側乫起飞吻合する。

内側翼突筋神経, 鼓膜張筋神経, 口蓋帆張筋神経 耳神経節の中で内側翼突筋神経, 鼓膜張筋神経, 口蓋 帆镸筋神経の 3 枝に分れるが，との付れる前の共通幹 に内上方からの神経節細胞の連絡が明らかである。向 耳神経節の後方へ伸びる内侧乫起下部から鼔膜镸筋後

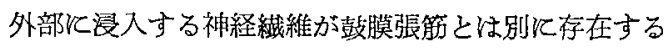
が，筋の中で瓦に連絡することなく終つている。

下影神経硬膜枝 耳神経節内側突起の上側先端近く から極く細い神経瀻維が，中硬膜動脈と上錐体静脈洞

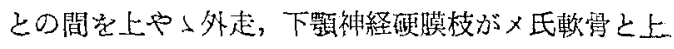
錐体静脈洞との間で後外上方へ曲る部分に合する。

耳介側頭神経 耳神経節外部力䅹く細い3条の神

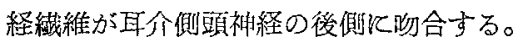

鼓索神経 耳神経節の下外部から 2 条の神経紻維が. 鼓索神経场合し，これを合せた鼓索神経はすぐ前方 で舌神経化連絡する。

向中硬膜動脈が耳神経節贵貫く部分からこの動脈の

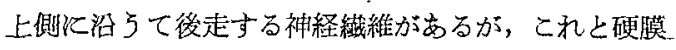
枝と接近しているにも不拘, 両者間の連絡壮判然しな い。又耳神経節内側突起から中硬膜動脈の下側飞沿 5 て後走する神経瀻維があつて, これから耳神経節と顔。 面神経膝とを結ぶ神経細胞索細い2 条の吻合があ り，佾この直後で前述の中硬膜動脈の上側に沿 5 神経. 裁維にる吻合がある。

外転神経（図 12, 図 13, 図 14）脳膜竟貫き蝸牛 部と鞁背との間を前や'内方へ向い，海綿静脈洞の略 略中央学通過，内頙動脈之上錐体静脈洞之の間加眼 静脈内側前方へ向5。小翼の下で動眼神経と鼠毛梯。 体神経上の間を内外の方向认走る極く緗い神経瀻維で 前頭神経上吻合している。

顔面神経（図 13, 図 14, 図 15) 内耳神経の上前

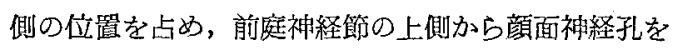
通り, 顔面神経滕江達し, 鼓室蓋の前方から外後方, 次いで後下方へ向つて弧を描いて曲り，砧軟骨長脚の 後側を通つてラ氏軟骨後端の外や」後よりからラ氏軟 骨之顎二膜筋後腹との間汇出て前や〉内走, ラ氏軟胃 外側から次第に離れ乍ら外耳道の下側を通つて終枝に 分れる。顔面神経と中間神経との識別山困難である。 晌前庭神経節の上を通る部分にこの神経節と速絡のな 以神経細胞小策団を認め，父颜面神経から前庭神経節， の中を通過するすのが若干ある。

顔面神経滕 Geniculum nervi facialis (図 15)

顔面神経孔の外側の出口に在り, 略々円形て顔面神 経の上側治入し, 前部治大浅錐体神経, 小浅錐体神 経がこれに入り，神経細胞索によつて耳神経節と吻合 し, 後下部に前庭神経節及この神経節の末梢の前庭神 経から極く細い神経繊維の吻合がある。

大浅錐体神経（四 10, 図 11, 図 14, 図 15) 顔面 神経滕の前端加前方へ翼口蓋神経節江達する。

小浅錐体神経（図 10，図 11）顔面神経腹前端少方 耳神経節の内側突起達する。

鐙骨神経・砧軟骨長脚の後側庭张状に走る顏面神経 の内側加直ぐ内側に在る鐙管筋江極く紐、鐙骨神経。 


$$
\text { (901) -- } 43-
$$

を分枝する。

鼓索神経（図 11, 図 13, 図 14, 図 15) 5氏軟骨 と顠二腹筋後腹との間で前方へ向を変えた顔面神経か ら閻もなく鼓索神経が上や小外方へ向つて分枝する。 鼓案神経はラ氏軟骨の前を上内方へ弧を描いて走り， 砧軟骨長脚と棺軟骨柄との間を通過，後者に沿５て前 走し，始めはメ氏軟骨の内側接しているが，次第に ×氏軟骨から離れて後方から舌神経に入る。

耳介後神経（図 15）鼓索神経が分枝するすぐ末梢 で僅か離れて 2 条の神経が外上方へ向5。

二腹筋枝（図 15） 前記 2 条の神経の分枝部の中間 位から外下方へ向つて䋖、二腹筋枝が分枝し，直ぐ外 側にある影二腹筋後腹に入つて箭の中を前方へ向う。

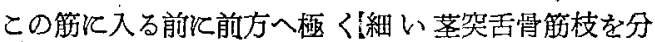
枝し，ラ氏軟骨の外側加ら下側へ廻り乍ら外方から茎 㔖专骨筋に入る。

内耳神経 顔面神経の後下側の位置を卢めて内耳孔 に入り，前庭神経と蝸牛神経とに分れる。

舌咽神経（図 12, 図 13, 図 14, 図 15) 頸静眽孔 の中で内神経節の内下部，孔を出て内神経節よりや上 大きい丸い外神経節の略々中央を通り，亏民軟骨の内 側，内頸動脈の外側圶通り，迷走神経加ら次第に離れ る。始めは茎突咽頭筋の内側に在るが，次第にその下 側飞迴り，この筋の前端加ら前走，咽頭近づき䅂枝 に分れる。

外神経節の少し中权側で舌咽神経から内頸静眽上壁 に接して外方へ向 5哣い神経緎維がある。

鼓室神経 外神経節加䗁牛部下面《沿5 て外方へ 分枝する鼓室神経は，Promunturiumの彎曲に従つて 外や小前方へ向い，蜎牛部外面に接し乍 走，次いで上〉外方へ向を変光，蝠牛部から㒕れて 顔面神経䐂前端に入り，小浅錐体神経に移行する。

頸鼓神経（図 14）鼓室神経加ら Promunturium K 沿 5 て前方へ向い分枝する上下 2 条の頸 鼓神経があ り，上の枝螖牛部外面から次第に離れて後方から内 頚動脈神経外側枝に達し，下の枝は上の枝より短く，上 の枝の吻合部の下方で内頸動脈神経外側枝に達奇る。

耳管枝（図 13）项鼓神経の上の枝の始まりの部分 からら上の枝と下の枝との間を前方へ向う耳管枝が出て いて，耳管の鼓室口内側部に逆している。

上頚神経節，節状神経節との連緦枝（図 14）外神 経節加前方へ分枝する神経瀻維は上下の 2 枝江分 れ，上の枝は前方で後から上頚鼓神経の上内後側に達 し，下の枝は後方で節状神経節の上後内側に達する。
上神経節は内頸動脈の内側で蝸牛部前部の下側から 頭長筋の起始部の外側飞搪がる大きい神経節で, その 上部加ら内项動脈の内外倿する太心内頸動脈神経内 側枝及外側枝が上方へ走る。

呕頭枝, 上頸神経節之の連絡枝 内頸動脈の外側で 本幹下部から哂頭枝及上頸神経節との吻合枝が 1 条前 方へ分枝し，面ちに内外の 2 枝江分れ，内側の咽頭枝 は前や」内下方へ向い，咽頭静脈丵の中に入つて上， 中，下の3枝に分れて咽頭垶に達し，との3枝間に交 通枝がある。外側の上頸神経節との吻合枝は，上神経 節中央外部に達する。向この内外の 2 枝に分れる前に 節状神経節中央外部加ら出る迷走神経咽頭枝との間に 吻合がある。

茎突咽頭筋枝 ラ氏軟骨前端の内下方で隣在する茥 突咽頭笵に紐短の茥突㖞頭符枝を分枝与る。

迷走神経（図 12，図 13，図 14，図 15）内频静脈 の内側にあつて頸静脈孔の中で頸静脈神経節に入り， これから出ると再び内頚動脈と内頸静眽との間に介在 する大きい棒状の節状神経節に入る。亥静脈神経節と

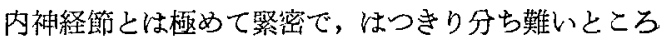
がある。節状神経節の全長に造つて舌下神経がその 背側から外側化接している。

頸静脈神経節のすぐ末梢で副神経内側枝が迷走神経 飞入り，節状神経節の略々中央部加上上前方入呕頭枝 が分枝し，すぐ舌咽神経の咽頭枝㛐絡する。この神 経節のすぐ末梢で粎走神経本幹から上頸神経節内側部 に接し乍ら上腒頭神経（図12）が前方へ分枝し，上頞 神経䬦之る吻合を示し，内頚動脈之外頙動脈との間を 通つてから内外の 2 枝飞分れ，内側枝忙上搌頭動脈之 共に甲状乾骨上角の直ぐ上側に，外側枝は下方へ向う。

副神経（図 14，図 15）頸静脈孔の中で頸静眽灼経 䬣の下部に撚合するが, 项静脈孔の出口附近で内外 2 枝に分れ，内儧枝はとのま小迷走神経に入り，外側枝 壮頸静哌孔を出て節状神経節と内頸静㟲との間を下行 する。

舌下神経（図 12, 図 13, 図 14, 図 15) 舌下神経 管中を 2 条の神経束に分れて前やや外下走，この神経 管を出て 1 条となり迷走神経に接近，節状神経節の背 側から外側へ建り，次いで内下方へ向い，迷走神経か ら次第に遠ざかつて外頸動脈の外側，顔面静脈の内側 を通り, 顎二腹筋後腹, 䒝突舌骨筋の外側から内側人 廻り，茎突舌骨筋之舌軟骨大角との間を前方へ向う。

舌下神経管中で内後方へ向う神経繊維が出る。節状 神経節後外側で舌下神経に頸神経から入る吻合枝があ 
る。との他総政動眽と顔面静脈との間で前下や」外方 へ出る下行枝, 茎突舌骨筋と舌軟骨大角との間で前や 、内下方へ向 万用状舌骨筋枝とがある。

\section{総括}

著著の $40 \mathrm{~mm}$ 人胎睍の耳管附近の軟骨，骨，筋， 動脈, 静脈及神経の相互の発生状態は前述の道りであ つて，とれを要約すると次の通りである。

軟骨は Dickie(1914), 栗原 (1955) の $20 \mathrm{~mm}$ 人胎 罗より著しく発育が進しでいて，Macklin (1914) の 例に近く，乙れ較へて幾分幼弱の段階飞あるるのと 思われ，就中トルコ鞍の形成が後れ，前靳突起，鞍背 突起及下垂体窞は Macklin の例程明嘹でない。且 Macklin \&蝸牛部の上側飞 cartil. supracochl., 基 底板の外側飞 cartil. parasphenoid. の発生を記载し ているが，著者の人胎児にはこれらの軟骨の発生は認 められない。高田士の（1949）2１0 ケ月の人胎览の 耳管の研究に上れば胎生 3 ケ月て咽頭口の外側に軟骨 外板の原基と思われる組織が発生し，4ケ月には前軟 骨性組織が耳管の内外㑡几沿つて長さを增すという。 㕛北川（1949）によ机泾耳管軟骨々胎生 3.万月末期或 注45月第一次原基分峡部下方，咽頭鼓室管中央部 後方及鼻咽顽開口部附近の 3 ケ所加方発生し（陕部下 方の原基は現れない事がある，3 原基が融合を終つて 主軟骨を形成する頃, 即, 胎生 5 6 ケ月頃から好え て陕部下方, 主軟骨下方及後方に 7 60 ケの第二次原 基が発生し始め，疆て第一次，第二次原基が合して耳 管軟骨注形成されるといふ。著者の胎览柱第 3 ケ月始 めから中ばまでの大いさであるから軟骨原基は期待出

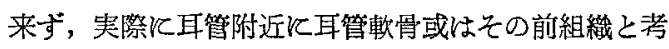
えられる組織は全く認められていない。

骨の発生㾁 Macklin の例之略略同様で, 側頭骨镂, Tympanicum, 将来檤軟骨の前突起となる Goniale 等 が発生している。

筋は例外なく所定の位置に発生して居り，その形㿟 戊人の形態似ていて，筋の分類に役立ち，神経支 配を成人一般の支配関係に一致している。

高田士によると胎生 2 ケ月で鼓膜原基は塊状を呈 乙, 槌軟骨柄は鼓室外側内面江沿つて下垂し, 砧軟 骨，鐙軟骨も胎生前半期まで周囲組織中に埋没する。 胎生 3 ケ月の明頭鼓室管及鼓室腔は上端が外方へ旋転 乙，咽頭口ほ縦记開口儿，胎生 3 ケ月末洇頭口附近

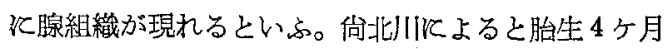
で耳管混合腺ね alveotubulöse Drüse を形成し，具 管惼桃は胎生 5 ケ月以後に現牥れるといふ。著者の人
脂児では鼓膜原基は上下の方向に少しく長い円形板状 で，鼓室腔へ椎軟骨柄乫出し，耳管の咽頭口の横断面 は上下に向く棈円形を呈し，全長とるたつて腺組織は 全く認められない。

外项動脈の主要分枝は例外なく現れている。Dickie の $20 \mathrm{~mm}$ 人胎児では $13-14 \mathrm{~mm}$ 人胎览で発生すると 云はれる A. stapedialis (Corning) が鋽軟骨輪中を 通つているが，著者の人胎児ではこの動脈は萎縮退化 しつょる。

主要静眽る殆んど現れ，一般慟脈よりる可なり太 い。海綿静脈洞㥛めて大きく, 下影後静脈は紐く曲 折しているのが特異てある。Streeter(1915)の $24 \mathrm{~mm}$ 人胎児ては下錐体静脈洞は形成されていないが，著者 の人胎児では現れていて中央が2条に分れている。

$\operatorname{Dixon}(1896)$ そよると， $6.9 \mathrm{~mm}$ 人胎巟で下類神経 の運動根 (Portio minor) が, $9.1 \mathrm{~mm}$ 人胎坚で鼓索 神経, 耳神経節, 外神経節加 5 外方一出る短い Jacobson の神経等が現われ， $13.6 \mathrm{~mm}$ 人胎児で下頻神経 の総ての主要分枝が現われ, 鼓索神経は舌神経と連絡 し, $17.5 \mathrm{~mm}$ 人胎览で下硕神経本幹の後内側儿在る耳 神経節加ら内方へ伸びる㔖起が半月神経節の内下面化 接するといふ。凤 Dickie $20 \mathrm{~mm}$ 人胎归で，鼓索 神経, Jacobson の神経を諗めている。著者の $40 \mathrm{~mm}$ 人胎贤で脳神経の分枝は前記の如く正常に現われて いて, 耳神経節加ら出る神経細胞性の突起は顔面神経 の㮏神経節汇連絡している。

耳管及豉室についての所胃を総括して見るに，軟口 蓋後部の後上方前や」内上方へ向つて開口する耳管 の咽頭口がある。こ」から经管は水平後外方へ走る のである。この咽頭口の形功，その開口の下後側に 隆起があつて，この開口を围んでいる事が考允られる が，口蓋帆挙筋はこの間胚葉性の譬の基部にあってと の中核えど入つていない。この筋はこの開口始 まつて耳管の下壁の上皮細胞層の直下を内側よりの位 置で走り，耳管鼓室口の下に達して終っている。この 口蓋帆举筋の外上側炕耳管上皮層加少し離九て口蓋 帆張筋がある。この口蓋帆張筋の外側认は内側翼突筋 上部が接し，この両筋のすぐ上方飞外側より飞側頭翼 軟骨の内下縁があつて，この軟骨はこ〉から外や」上 方へ伸びる。上方内側よりには口蓋骨原基があり，㸶 頭上皮首に接近している。李た口蓋帆挙筋の下側には これより滛か、大きい頭咽頭笳が咽頭上皮圆に接して 存在する。外側の側頭翼軟骨と内側の口蓋骨とで上方 へ囲まれる部分は眼窝の後方の部分に当り，こっ飞翼 


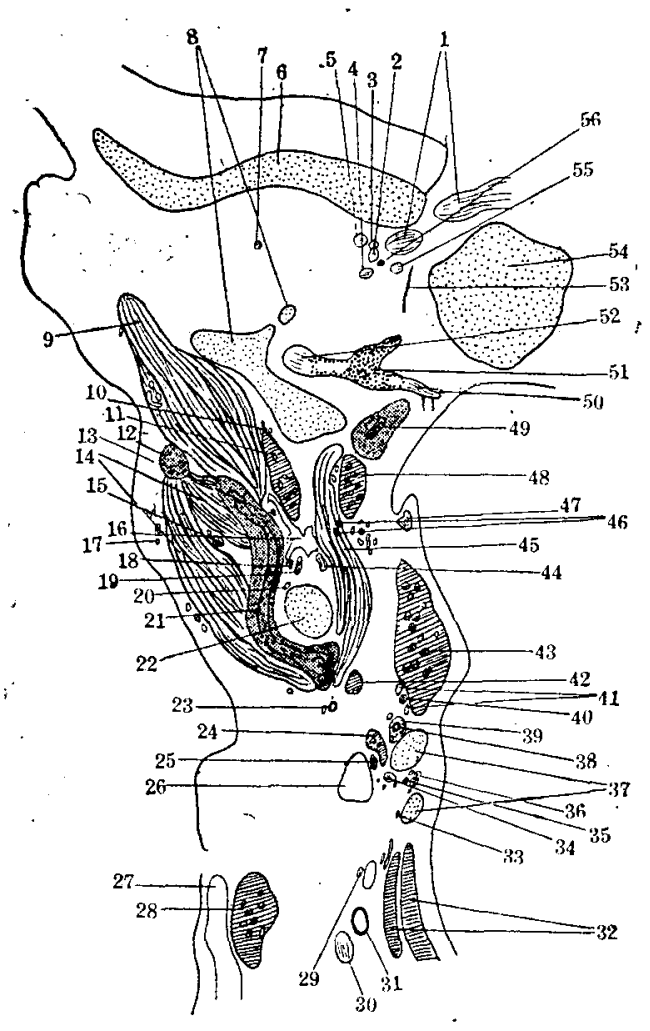

1 ...視束

2 …鼻毛様体神経

3…滑車神経

4 …外転神経

$5 \ldots$ 前頭神経

$6 \cdots$ 眼窝翼

7 …涙腺神経

$8 \cdots$ 側頭翼

9 ...側頭簃

$10 \cdots$ 煩神経

11 …外側翼突䇽

$12 \cdots$ 側頭骨煩骨突起

13 …㕮筋動脈

$14 \ldots$ 咬筋

15 …咬觔神経

16 …翼突䇟静脈丵

$17 \cdots$ 颜面横静脈

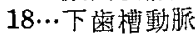

19 ...下齿榑神経

$20 \cdots$ 顎舌骨神経

21 …下顎骨

$22 \cdots \times ッ ケ ル 氏$ 軟骨

23…顔面動脈

$24 \cdots$ 茎突舌骨筋

$25 \cdots$. 顎二腹筋後腹

26 …顔面静脈

$27 \cdots$ 外側浅頸静脈

$28 \cdots$ 胸鎖乳突筋

29...舌下神経下行枝

$30 \cdots$ 迷走神経

$31 \cdots$ 総頸動脈

32…舌咽頭筋亚飞知頭咽頭筋

33 ...上甲状腺動脈

34...舌下神経

$35 \cdots$ 上吸頭動脈

36 …上喉頭神経内側枝

$37 \cdots$ 舌軟骨大角並飞甲状般骨上 角

$38 \cdots$ 舌動脈

39 …舌骨舌筋

$40 \cdots$ 舌咽神経

$41 \cdots$ 舌静脈

$42 \cdots$ 䔄突舌筋

$43 \cdots$ 頭咽頭筢

$44 \cdots$ 舌神経

$45 \cdots$ 内側翼突的

$46 \cdots$ 内側翼突筋神経

$47 \cdots$ 口培邨挙能

$48 \cdots$ 口蓋帆張筋

$49 \cdots$ 口蓋骨

50 …亶口蓋神経

51 …翼口蓄神経節

$52 \cdots$ 上顎神経

$53 \cdots$ 眼窝枝 (内側枝)

$54 \cdots$ 眼䆚間障

$55 \cdots$ 县眼神経

$56 \cdots .$. 跟動秛

図 $1240 \mathrm{~mm}$ 人胎览の頭部前頭断（切片175）

口蓋神経節と上類神経とが内外飞並び，乙の神経節の 内下部から内下方へ拿口篮神経が出る。この神経は出 るとすぐに咽頭上皮粕直下に達し，反刘側の神経と接 近する。この神経の外側枝は耳管咽頭口附近の上溉に

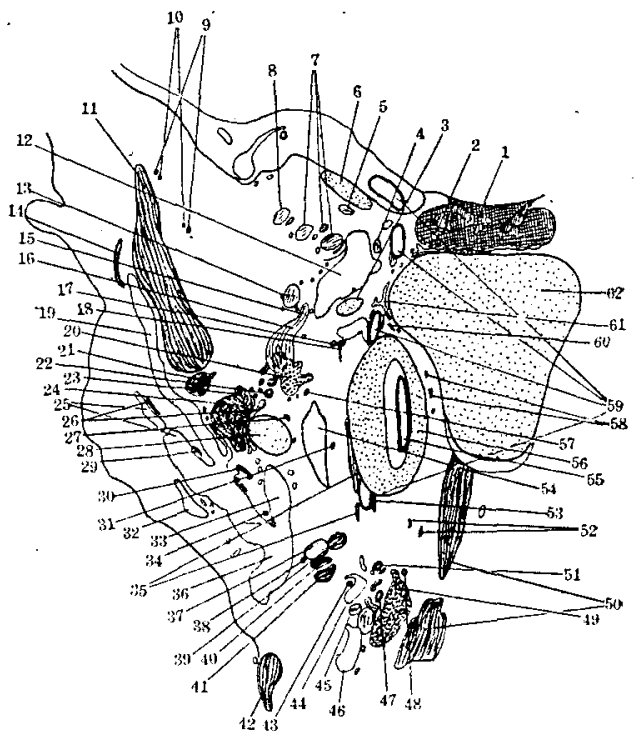

1 ...下垂体

$2 \cdots$ 海綿間静脈洞

3 …翼突起

$4 \cdots$ 外転神経

$5 \cdots$ 動眼神経

$6 \ldots$ 小翼

7 ...眼神経

8 …滑本神経

$9,22 \cdots$ 中硬膜動㭛

10 …中硬膜静脈

11 ...侧頭筋

$12 \cdots$ 上錐体静脈洞

$13 \cdots$ 上颚神経

$14,30 \cdots$ 浅側頭動㟲

15 ...Portio minor

$16 \cdots$ 下顎神経

17…大浅錐体神経

18…大浅錐体神経と内頸 動脈神経外側枝との 連絡枝

$19 \cdots$ 中側頭静脈

$20 \cdots$ 耳神経節

21 …側頭骨煩骨㔖起

$23 \cdots$ 外側翼突筋

$24 \cdots$ 下顎骨

$25 \cdots$ 浅侧頭静脈

$26 \cdots$ 耳介側頭神経

27 …鼓索神経

$28 \cdots$ ‥ラル氏軟骨

29 …顔面神経

31 …鼓室神経耳管枝
$32 \cdots$ 外耳道

$33 \cdots$ 顎静脈

$35 \cdots$ 内頸動㢳神経外侧枝

$36 \cdots$ 浅頸静脈

$37 \cdots$ ライヘルト氏軟骨

$38 \cdots$ 耳分側頭動脈

$39 . .$. 茎突咽頭符

$40 \cdots$ 茎突舌骨筋

$41 \cdots$ 颚二腹筋後腹

$42 \cdots$ 胸鎖乳突筋

$43 \cdots$ 後頭動脈

$44 \cdots$ 咽頭静脈

$45 \cdots$ 吉下神経

$46 \cdots$ 内镍静脈

$47,59 \cdots$ 内頸動脈

$48 \cdots$ 上行咽頭勤脈

$49 \cdots$ 上頸神释節

$50 \cdots$ 頭長筋

$51 \cdots$ 舌咽神経

$52 \cdots$ 上行咽頭動脈内側枝 (咽頭枝)

$53 \cdots$ 内頸動脈神経内側枝

54 …暒室曌

$55 \cdots$ 蝸牛管

$56 \cdots$ 蛤牛部

$57 \cdots$ 鼓膜張筋神経

$58 \cdots$ 内頙静脈裳之咽頭静脈 との連絡枝

$60 \cdots$ 内顠静㟲

$61 \cdots$ 海綿静脈洞

$62 \cdots$ 基底板

図 $1340 \mathrm{~mm}$ 人胎児の頭部前頭断（切片 204 ) 
達している。要するに耳管は口蓋骨の後端, 側頭翼の

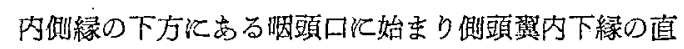
下に沿つて後外走, 僛頭翼が頭蓋底軟骨へつぶく部 分の下を少し離れて通り，蝸牛部先端の外側に達する が, こ〉で耳管の直後を上下の方向に内頸動脈が通つ ている。これに続く鼓室は蝸牛部の外側下部に在 る。(図 13) 内頸動眽々蝸牛部先端の外側飞直接乙,

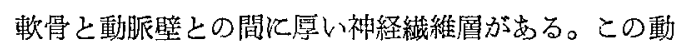

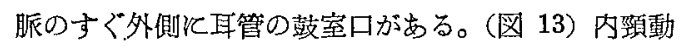
眽の外側を通る大浅錐体神経と動眽周囲加らのびる深 錐体神経之は蝸牛部前端上縁の外側方, 鼓室腔前端部 の上方飞や小離れた位置にあり，これらの神経は前走 して，側頭翼が頭蓋底軟骨へつがく部分の直下，さら 飞前方は側頭翼内側縁の内側飞沿 万て通る翼突管神経 となる。内頸動脈の外側に沿う神経から大浅錐体神経 飞連絡する枝がある。

口蓋帆挙筋の終つている部分に相当している耳管の 鼓室口は内頸動脈の外側, 耳神経節の内下側, $x$ 氏軟 骨の内上側の位置を占めている。耳神経節估鼓室の外 上方にや上離れて位㯰し, その内側前よりに口蓋帆張 筋が接触して居る。田中が成人について得た所見によ ると，耳神経節は耳管軟骨と下頸神経との間にあっ て，その後端は中硬膜動脈の壁と接し，口蓋帆張筋の 筋膜儿屡瘘被われているという。この例で注中硬膜動 脈は耳神経節の外側を僅か貫通している。

鼓室の外側にメ氏軟骨，この軟骨のすぐ下㑡に太い 影静脈があり, その内側, 鼓室前端部の下側飞や小離 れてラ氏軟骨がある。外耳道的外方から内方や小下よ りと傾き作らのびて鼓室の外側に達し，鼓室底より少 乙高い位置沉終つている。外耳道と鼓室との上皮細胞 層の間の薄い結締織性の膜が呚膜原基で，この原基の ある部位は舫軟骨唡の先端より前方に位置し，これよ り後方へは殆えどひろがつていない。鼓室腔もその後 方で間もなく終つている。鼔宝院の前後の中央部に於 ける周囲との関係を見ると，(図 13，14）腔山軟骨表 面の彎曲江沿5て外上方から内下方へ傾き，之の外側 そ接している外耳道底の上皮層は院ほどは広がつてい

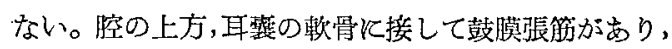
そのすぐ外側，空の上外方にメ氏軟骨，この軟骨の腔 飞向う表面飞 Goniale 及 Tympanicum があり，腔 の下内側端の直下，外よりにラ氏軟骨及これと近い関 係の筋, 動脈があり，その内下方治内頚静脈がある。 腔の後端部，樋軟骨柄の突出している部分ではこのた め腔が上下に区分され，上側は内外へひろがつている

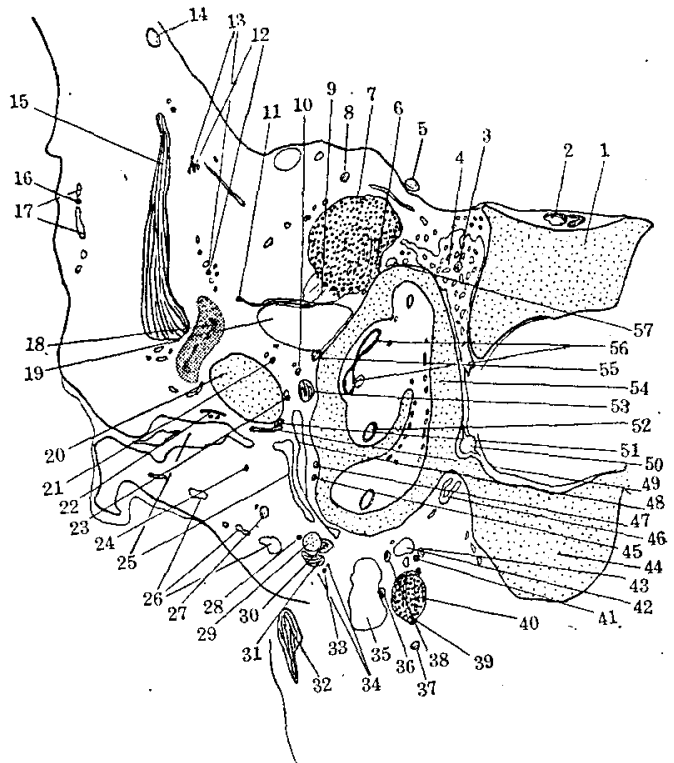

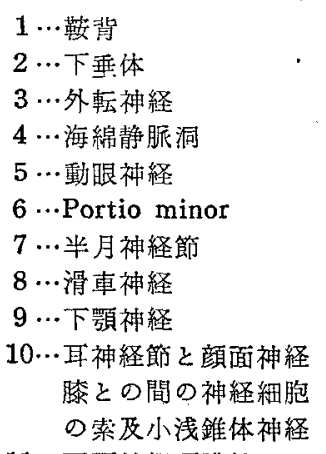

11 …下顎神経硬膜枝

$12,21 \cdots$ 中硬膜動脈

$13 \cdots$ 中硬膜静脈

$14 \cdots$ 背側突起

$15 \cdots$ 側頭筋

16...浅側頭勳脈

$17 \cdots$ 浅側頭静脈

$18 \cdots$ 側頭骨媔骨突起

$19 \cdots$ 上錐体静脈洞

$20 \cdots \times ッ ケ ル$ 氏軟骨

$22 \cdots$ 前耳介神経

$23 \cdots$ 鼓索神経

24 …外耳道神経

$25 \cdots$ 外耳道

$26 \cdots$ 耳介後静脈の分枝

27 …顔面神経

28 ...每介後勤脈

29 …ライヘルト氏軟骨

$30 \cdots$ 菱突咽頭崭

$31 \cdots$ 顎二腹筋後腹

$32 \cdots$ 胸銧乳突筋

$33 \cdots$ 後頭動脈

$34 \cdots$ 後頭静脈

$35 \cdots$ 内頸静脈

$36 \cdots$ 副神経

$37 \cdots$ 舌下神経と頸神経との 連絡枝

38…舌咽神経

$39 \cdots$ 舌下神経

$40 \cdots$ 節状神経節

$41 \cdots$ 上行咽頭動服外側枝

$42 \cdots$ 呕頭静脈

$43 \cdots$ 舌咽神経と_上頸神経節 及節状神経節之の連絡 枝

$44 \cdots$ 基底板

$45 \cdots$ 鼓室神経耳管枝

$46 \cdots$ 内頸静派裳之咽頭静脈 との連絡枝

$47 \cdots$ 頸鼓神経上侧枝

$48 \cdots$ 鼓空空

49...Tympanicum

$50 \cdots$ 下踓体静脈洞

51 ... Goniale

$52,56 \cdots$ 蛹牛管

$53 \cdots$ 鼓膜張筋

$54 \cdots$ 蛤牛部

$55 \cdots$ 大浅錐体神経

$57 \cdots$ 前庭部の内方から上錐 体静脈洞飞連絡する静 㟲

図 $14.40 \mathrm{~mm}$ 人胎児の頭部前頭断（切片222） 
が，下側䅈く，乙の部分より後方へ行くにつれて上 側の腔は縮少，消失し，軟骨下方飞接する単一の腔と なり，最初は矢張り外上方から内下方へと攧いている が，次第に後炈なるつれて，この傾が強くなつて

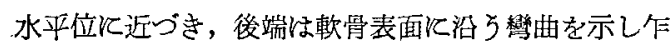
ら水平位で終る（図 5 )。この後端部の上方沾軟骨 及鐙軟骨，前庭密が来る。

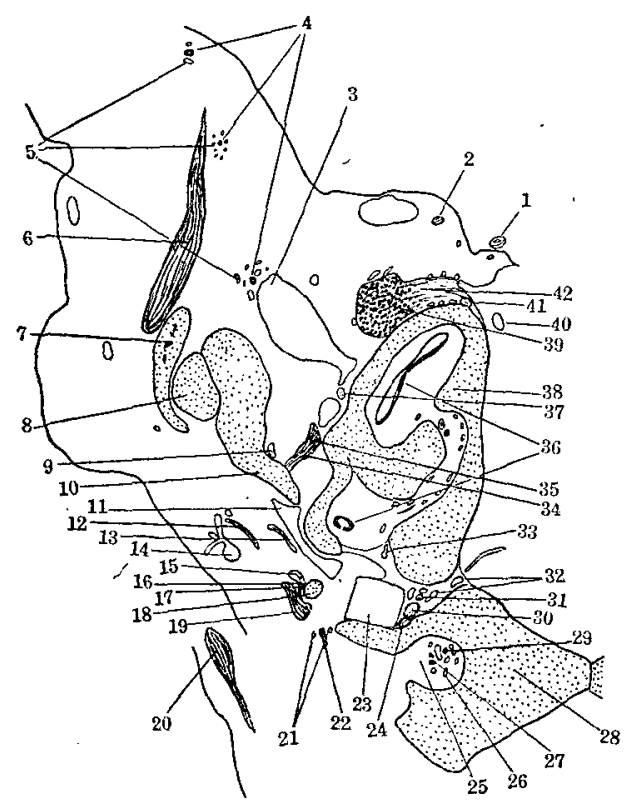
$1 \cdots$ 動眼神経
$2 \cdots$ 滑車神経
$3 \cdots$ 上錐体静脤洞
$4 \cdots$ 中硬膜動脈
5 …中硬膜静脈
$6 \cdots$ 唰頭䈥
7 …側頭骨
$8 \cdots$ 砧软骨
9 ...敋索神経
10…槌軟量
11 …鼓室腔
$12 \cdots$ 䫠面神程の分枝
13 ...外耳道
$14 \cdots$ 年介後静眽
$15 \cdots$ 顔面神経
16…顔面神経二腹筋枝
$17 \cdots$ 茎乳架孔動脈
18…ライヘルト民軟骨
19 ...顎二腹筋後腹
$20 \cdots$ 胸鎖乳突筋
$21 \cdots$ 後頭動脈
$22 \cdots$ 後頭静脈
$23 \cdots$ 内頸静脈
$24 \cdots$ 副神経
25 …苦下神経管
26 ...舌下神経管静脈網
27 …舌下神経
28 ...後頭部
$29 \cdots$ 上行咽頭動脈の分枝
30 …迷走神経
31 …舌咽神経
$32 \cdots$ 下錐体静脈洞
$33 \cdots$ 蝸牛小管静脈
$34 \cdots$ 鼓䑏張筋
$35 \cdots$ 顔面神経膝
$36 \cdots$ 蝸牛管
$37 \cdots$ 大浅雓体神経
$38 \cdots$ 螖牛部
$39 .$. 半月神経節
$40 \cdots$ 前庭部の内方から上錐 体静脈洞飞連絡する静 嫄
$41 \cdots$ Portio minor
42 ...Portio major

図 $1540 \mathrm{~mm}$ 人胎巟の頭部前頭断（切片 $243 ）$
鼓䒺神経が舌神経から後方へ分れる部分は耳管鼓室 口のすぐ外前方の位置化当るが，この神経はメ氏軟骨 の内上側をこれに沿つて後走し，これに対して鼓空腔 は蝸牛部の外側面飞沿つて前方はメ氏軟骨の内側飞あ るが，後方程との下側にずれて来る。故にメ氏軟骨に

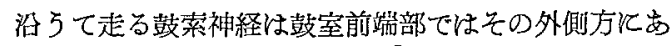
るが, 後端部では上方へずれ，後走するにつれて鼓室 から次第に離れて棺軟骨と砧軟骨との間を通つて鼓室 腔後端の外側を少しはなれて通り，その直後の位置で ラ氏軟骨の外側沿うている顔面神経に入る。

鼓膜張筋々耳神経節の内下側の組織加ら細い絾維束 で始まり，次第に太くなり乍ら鼓室のすぐ上方沿つ

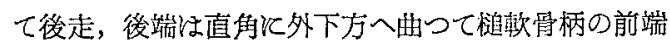
飞近く，并の内側附着士。(図 15)。

顔面神経注膝神経節から後方, 次いで後下方へ曲

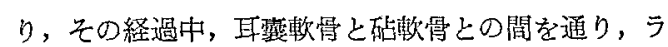
氏軟骨の外方に出る。

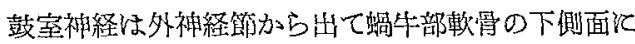
沿つて外方へ走り，蝸牛部软骨首之鼓室上皮細胞層之

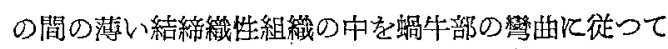
曲り乍ら上㫧，次いで顔面神経滕前端炕入り，小浅錐 体神経となつて前走, 耳神経節に入る。部室神経加ら 分れる 2 架の项鼓神経す鼓室上皮細胞層と蛹牛部軟骨 喉との間を後者倿して前走, 欶骨表面淁し乍ら走 る内頸動脈外側の神経枝に達し，その中の上の頸鼓神 経から分枝する耳管枝は耳管鼓室口の外側部達して 終る。豊田の成人についての所見に上ると頸枝神経の 入つている内頸動脈神経叢から出る枝が Torus tubalis 飞達し，直接頸鼓神経の分枝が耳管に達して ないが，この $40 \mathrm{~mm}$ 人胎览例では神経丵から来るも のは認められず，直接频站神経の分枝が耳管に達して いる。

耳管周囲の間怔葉組織は一般とゆるいが，鼓室口附 近では幾分細胞が密集している。併しその状態は前軟 骨性ではない。耳管の上皮は 4〜5 首の細胞首から成 り，その表面记顔毛を認めるが腺組織は全く存在しな

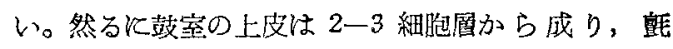
毛覀無い。

$$
\text { むすび }
$$

$40 \mathrm{~mm}$ 人胎児の耳管は，口藍後端部の上万厉，前上 方へ向く咽頭口飞始まり，殆ど水平行後方へ側頭翼 内側縁の下方に沿いつら゙き，耳虂の直前外よりで，上 下に走る内頸動脈の直前を横切つてその外側飞出て, 鼓室腔に移行する。この移行部の外上方に耳神経節が 
ある。鼓室腔は始めは耳管の腙に引つよ゙，上下に細 長いが，内預動脈の外後方飞始まるこの腔は，後端ま で耳慗の軟骨のすぐ表面㳂うて居り，従つて腔の中 央部は軟骨の凸慗曲沉治了て彎曲して居り，上下垂直

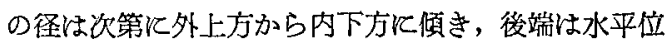
となつて終つている。その上皮風と軟骨之の間の薄い

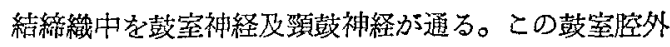
側江外道原基が達しているが，その広がりは腔程ひ ろくない。 Meckel 氏軟骨は鼓室䧑の前部ではその外 側にあるが，後方となるにつれてその外上方へずれ， 後部上方から檤軟䯈柄が前下方へとこの鼓膜原基中に 突出している。耳管の周囲《は軟骨原基は全くこれを 欠き，上皮は眠毛上皮であるが腺を欠く。鼓室では㕍 平立方上皮である。

高稿を終るに臨み終始御原情ある御指導御校閲を睗 わつた恩師横尾安夫教授飞讙んで感謝の意を捧げま 士。

\section{交献}

(1) Corning, H.K. : Lehrbuch d. Entw,-gesch. d. Menschen (1925)

(2) Dickie, M.D.: Journ. Anat, 48 (1914)

(3) Dixon, F.A. : The Scient. Trans of the Roy. Dublin Society, VI Series II (1896)

(4).Fischel, A.: Lehrbuch d. Entwicklung d. Menschen (1927)

(5) Keibel-Mall : Handb. d. Entw.-gesch. d. Menschen (1911)

（6）北川和男：日耳鼻，55，6,7(1952)

（7）栗原哲二：日医大誌，22，7 (1955)

(8) Macklin, C.C. : Am. Journ. Anat. 16 (1914)

(9) O, Schultze : Topographische Anatomie (1935)

(10) Rauber-Kopsch : Lehrbuch u. Atlas d. Anatomie des Menschen (1940)

(11) Streeter, G.L. : Am. Journ. Anat. 16 (1914)

（12）高田 士：熊大解剖教室業續， 2 (1949)

(13) Tanaka : Arbeiten aus d. III Abteilung d. anat. Institutes d. Universität Kyoto (1932)

(14) Testut, $L:$ Traité d' anatomie humạine, III (1911)

(15) Toyota : Acta Scholae med. Kyoto XI(1928)

\section{Résumé}

Topography of the auditory tube and the tympanic cavity in a $40 \mathrm{~mm}$ long human embryo. Sōjirō Takata

The pharyngeal opening of the auditory tube lies higher the hind margin of the palate which is not yet fused. It directs ventral and a little cephalic, so the margin of the opening is a little swollen dorsal and caudal. The tube continues almost horizontally hind and lateralward immediately before the ascending internal carotid artery and reaches lateral of it where lies the tympanic opening of the tube. This crossing artery has a thick nerve net immediately around it. The great superficial petrosal nerve from the ganglion geniculi comes from behind and lateral to lateral of the artery and turns foreward, continues parallel with the profound petrosal nerve from the nerve net of the artery and reaches the pterygopalatine ganglion. The auditory tube has a elliptic or trapeziform with a vertical long axis in thefrontal cut. (Fig. 5) The epithel of the tube consists of 4-5 layered flimmer cells, no praecartilageous nor glandular tissue.

The tympanic cavity begins lateral to the internal carotid artery which passes vertically on the lateral surface of the apex of the cochlear part of the otic capsule, and expands backward upon the surface of the cartilage. This foremost part of the cavity lies medial and beneath the otic ganglion, medial to the Meckel's cartilage. The cavity itself is in its middle part compressed mediolateralward, its vertical diameter is directed from dorsolateral to medioventral as one can understand in the figures. The Meckel's cartilage which lies lateral to the middle part of the cavity continues backward gradually higher to the cavity, so its continuation to the malleus comes very high to the hind part of the cavity. The manubrium mallei projects vertically down and a little medialward to the most hind part of the cavity, so can be the cavity in upper and lower parts divided. The upper half is mediolaterally a little wide, but it becomes smaller gradually backward and out of sight, the lower part extends backward beyond the upper part, becoming more and more horizontally and ends on the under surface of the cartilage completely horizontally. The fundus extension of the externa auditory meatus is not so large as that of the cavity, so that that of the thin mesenchymal tympanic membrane a little smaller than that of the cavity. The epithel of the cavity is cubic $2-3$ cells layered. The tympanic nerv and its rami caroticotympanici lie on the surface of the cartilage which covered with the epithel of the cavity. 